\title{
Integrin aV $\beta 3$ silencing sensitizes malignant glioma cells to temozolomide by suppression of homologous recombination repair
}

\author{
Markus Christmann ${ }^{1, *}{ }^{,}$Kathrin Diesler ${ }^{1}$, Dragomira Majhen ${ }^{2}$, Christian Steigerwald ${ }^{1}$, \\ Nancy Berte ${ }^{1}$ Halima Freund ${ }^{1}$, Nikolina Stojanović ${ }^{2}$, Bernd Kaina ${ }^{1}$, Maja Osmak ${ }^{2}$, \\ Andreja Ambriović-Ristov ${ }^{2}$, Maja T. Tomicic ${ }^{1, *}$ \\ ${ }^{1}$ Department of Toxicology, University Medical Center Mainz, D-55131 Mainz, Germany \\ ${ }^{2}$ Laboratory for Cell Biology and Signaling, Division of Molecular Biology, Ruđer Bošković Institute, HR-10000 Zagreb, Croatia \\ *These authors contributed equally to this work \\ Correspondence to: Maja T. Tomicic, email: tomicic@uni-mainz.de \\ Andreja Ambriović-Ristov, email: Andreja.Ambriovic.Ristov@irb.hr \\ Keywords: malignant gliomas, integrin aVß3 silencing, temozolomide, homologous recombination repair, Rad51 \\ Received: March 30, $2016 \quad$ Accepted: July 19, $2016 \quad$ Published: July 28, 2016
}

Copyright: Christmann et al. This is an open-access article distributed under the terms of the Creative Commons Attribution License (CC-BY), which permits unrestricted use, distribution, and reproduction in any medium, provided the original author and source are credited.

\section{ABSTRACT}

Integrins have been suggested as possible targets in anticancer therapy. Here we show that knockdown of integrins $\alpha V \beta 3, a V \beta 5, a 3 \beta 1$ and $a 4 \beta 1$ and pharmacological inhibition using a cyclo-RGD integrin $\mathrm{aV} \beta 3 / \mathrm{aV} \beta 5$ antagonist sensitized multiple highgrade glioma cell lines to temozolomide (TMZ)-induced cytotoxicity. The greatest effect was observed in LN229 cells upon integrin $\beta 3$ silencing, which led to inhibition of the FAK/Src/Akt/NFKB signaling pathway and increased formation of YH2AX foci. The integrin $\beta 3$ knockdown led to the proteasomal degradation of Rad51, reduction of Rad51 foci and reduced repair of TMZ-induced DNA double-strand breaks by impairing homologous recombination efficiency. The down-regulation of $\beta 3$ in Rad51 knockdown (LN229-Rad51kd) cells neither further sensitized them to TMZ nor increased the number of YH2AX foci, confirming causality between $\beta 3$ silencing and Rad51 reduction. RIP1 was found cleaved and IKBa significantly less degraded in $\beta 3$-silenced/TMZexposed cells, indicating inactivation of NFKB signaling. The anti-apoptotic proteins Bcl-XL, survivin and XIAP were proteasomally degraded and caspase-3/-2 cleaved. Increased H2AX phosphorylation, caspase-3 cleavage, reduced Rad51 and RIP1 expression, as well as sustained IKBa expression were also observed in mouse glioma xenografts treated with the cyclo-RGD inhibitor and TMZ, confirming the molecular mechanism in vivo. Our data indicates that $\beta 3$ silencing in glioma cells represents a promising strategy to sensitize high-grade gliomas to TMZ therapy.

\section{INTRODUCTION}

Despite constant progress in medical care, highgrade gliomas (WHO grade III - anaplastic astrocytomas and grade IV-glioblastomas) remain incurable. Ionizing radiation (IR) combined with the methylating anticancer drug temozolomide (TMZ) represents the standard therapy of these tumors [1]. TMZ induces various DNA adducts including $\mathrm{O}^{6}$-methylguanine $\left(\mathrm{O}^{6} \mathrm{MeG}\right)$, which is responsible for the anticancer activity. $\mathrm{O}^{6} \mathrm{MeG}$ can be repaired by the DNA repair protein $\mathrm{O}^{6}$-methylguanineDNA methyltransferase (MGMT). In the absence of MGMT, $\mathrm{O}^{6}-\mathrm{MeG}$ leads, via replication and the involvement of mismatch repair, to DNA double-strand breaks (DSBs). Importantly, $\sim 40 \%$ of all malignant gliomas are negative for MGMT $[2,3]$ and TMZ therapy is particularly effective in these tumors $[4,5]$. However, $\sim 60 \%$ of patients, whose tumors are proficient for MGMT, do not profit from the therapy. Thus, new strategies to overcome TMZ resistance in gliomas are urgently needed. One of these includes targeting of integrins.

Integrins are heterodimeric transmembrane glycoprotein $\alpha / \beta$ receptors that mediate cell adhesion and directly bind components of the extracellular matrix (ECM), thereby providing anchorage for cell motility and invasion. In addition, binding of integrins with 
ECM ligands induces a variety of intracellular signals and regulates cellular responses including proliferation, survival, migration and differentiation [6]. Activation of integrin receptors results in the association of multiple protein complexes, allowing integrins to transmit biochemical signals via tyrosine kinases such as focal adhesion kinase (FAK) or Src [7]. Integrin-associated proteins are involved in all major signal transduction pathways critical in determining the cell response to cytotoxic agents.

Integrins $\alpha \mathrm{V} \beta 3$ and $\alpha \mathrm{V} \beta 5$ are broadly expressed not only on blood vessels in brain tumors (glioblastomas), but also in tumor cells $[8,9]$. Various pharmacological approaches for modulation of integrin signaling have been explored including antibodies and peptide-based agents $[6,10]$. Indeed, treatment of tumors by integrin antagonist cilengitide (CGT) in the orthotopic brain model in vivo reduced tumor growth [11]. A clinical phase II study revealed that the concomitant and adjuvant addition of CGT, a cyclic $\alpha \mathrm{V} \beta 3 / \alpha \mathrm{V} \beta 5$ RGD mimetic [12], to the standard TMZ radio-chemotherapy showed promising activity in glioblastoma patients with MGMT promoter methylation [13]. Unfortunately, in the phase III study (CENTRIC) CGT failed to show advantage in comparison to the standard treatment [14]. One reason out of many for this failure could be that mainly $\alpha \mathrm{V} \beta 3$ and $\alpha \mathrm{V} \beta 5$ expressed on endothelial cells were targeted, while integrins expressed on tumor cells were inefficiently blocked $[15,16]$. Despite this inconclusive trial, integrins still remain an attractive target for cancer therapy, which is strongly supported by the present study. Also, the newest data conducted on tumor material of the CORE study (failed to show benefit of CGT in patients with MGMT positive tumors) [17] showed that $\alpha \mathrm{V} \beta 3$ expression correlates with better OS and PFS in CGT-treated patients with tumors expressing MGMT [18].

Since integrins promote many essential cellular functions, their knockdown by means of siRNA might be a promising approach to enhance the efficacy of tumor therapy. Here, we particularly focused on molecular pathways/signaling initially caused by silencing of integrin $\beta 3$ in glioblastoma cells. We show in cell culture in vitro and in a xenograft model in vivo that $\beta 3$ silencing suppresses DNA repair of TMZ-induced DSBs impairing homologous recombination (HR). Furthermore we provide evidence of the involvement of the Akt/NFkB signaling pathway in this process.

\section{RESULTS}

\section{Determination of integrin status in human malignant glioma cell lines}

Expression of integrin heterodimers ( $\alpha 3 \beta 1$, $\alpha 4 \beta 1, \alpha \mathrm{V} \beta 3$ and $\alpha \mathrm{V} \beta 5$ ), together with MGMT and p53 status in a panel of ten cell lines is shown in Table 1 and Supplementary Figure S1 (histograms). The p53 and MGMT activity (Table 1) were determined before $[2,3,19]$. Only two of the glioma cell lines (GBP61 and $\mathrm{U} 138 \mathrm{MG}$ ) were shown to express all four integrin heterodimers. Nine out of ten cell lines express $\alpha \mathrm{V} \beta 3$, indicating that this integrin might be a suitable therapeutic target for malignant gliomas. A total of seven cell lines were shown to express the $\alpha 4 \beta 1$ integrin. Out of the nine cell lines expressing $\alpha \mathrm{V} \beta 3$, we selected four lines for further investigation. These cell lines do not show MGMT activity which enabled us to achieve maximum TMZ cytotoxicity without MGMT inhibitor. We chose the U138MG cell line, showing expression of all four integrins, the glioblastoma cell lines LN229 and LN308, expressing $\alpha \mathrm{V} \beta 3$ and $\alpha 4 \beta 1$, but are characterized by a different $\mathrm{p} 53$ status $[19,20]$ and the U87MG cell line expressing $\alpha \mathrm{V} \beta 3$ and $\alpha \mathrm{V} \beta 5$, also used in the xenograft model.

\section{Integrin $\beta 3, \beta 5, \alpha V, \alpha 3$ and $\alpha 4$ silencing sensitizes malignant glioma cells to $\mathrm{TMZ}$}

In all analyzed high-grade glioma cell lines (LN229, LN308, U138MG, U87MG) the integrin subunit-specific siRNA transfection led to reduction in expression of corresponding integrins, whereas the control-siRNA had no effect. A representative example of integrin expression and of effective silencing, as quantified by mean fluorescence intensity (MFI), is shown for the LN229 cell line (Figure 1A). In order to concomitantly reduce the expression of $\alpha \mathrm{V} \beta 3$ and $\alpha \mathrm{V} \beta 5$, in some experiments cells were transfected with integrin $\alpha \mathrm{V}$-specific siRNA.

Silencing of the corresponding integrin subunits in the cell lines LN229, LN308, U87MG and U138MG clearly increased sensitivity to TMZ compared to the controlsiRNA, as shown by the MTT assay (for LN229 cell line, see Figure 1B-1D, for other cell lines, see Supplementary Figure S2-S4). Of note, the cells were exposed to TMZ for six days. Growth rates of the cell lines upon siRNA transfection were slowed down by $20 \%$ at maximum relative to the non-transfected control. We also determined reproductive cell survival by colony formation assay (LN229 Figure 1E and U138MG Supplementary Figure S2B) showing that each of the integrin-specific siRNAs led to a reduced clonogenic survival as compared to control-siRNA. The silencing of the integrin subunits $\beta 3$ led to the strongest sensitization effect upon TMZ exposure in all analyzed cell lines indicating that the integrin $\alpha \mathrm{V} \beta 3$ plays a crucial role in mediating TMZ sensitivity. The strongest sensitization effect was achieved in LN229 cells, thus we used this cell line for all further experiments.

\section{Integrin silencing and cyclo-RGD integrin inhibitor sensitize glioma cells to TMZ-induced apoptosis}

TMZ predominantly induces apoptosis in malignant glioma cells as a very late event [21]. A 

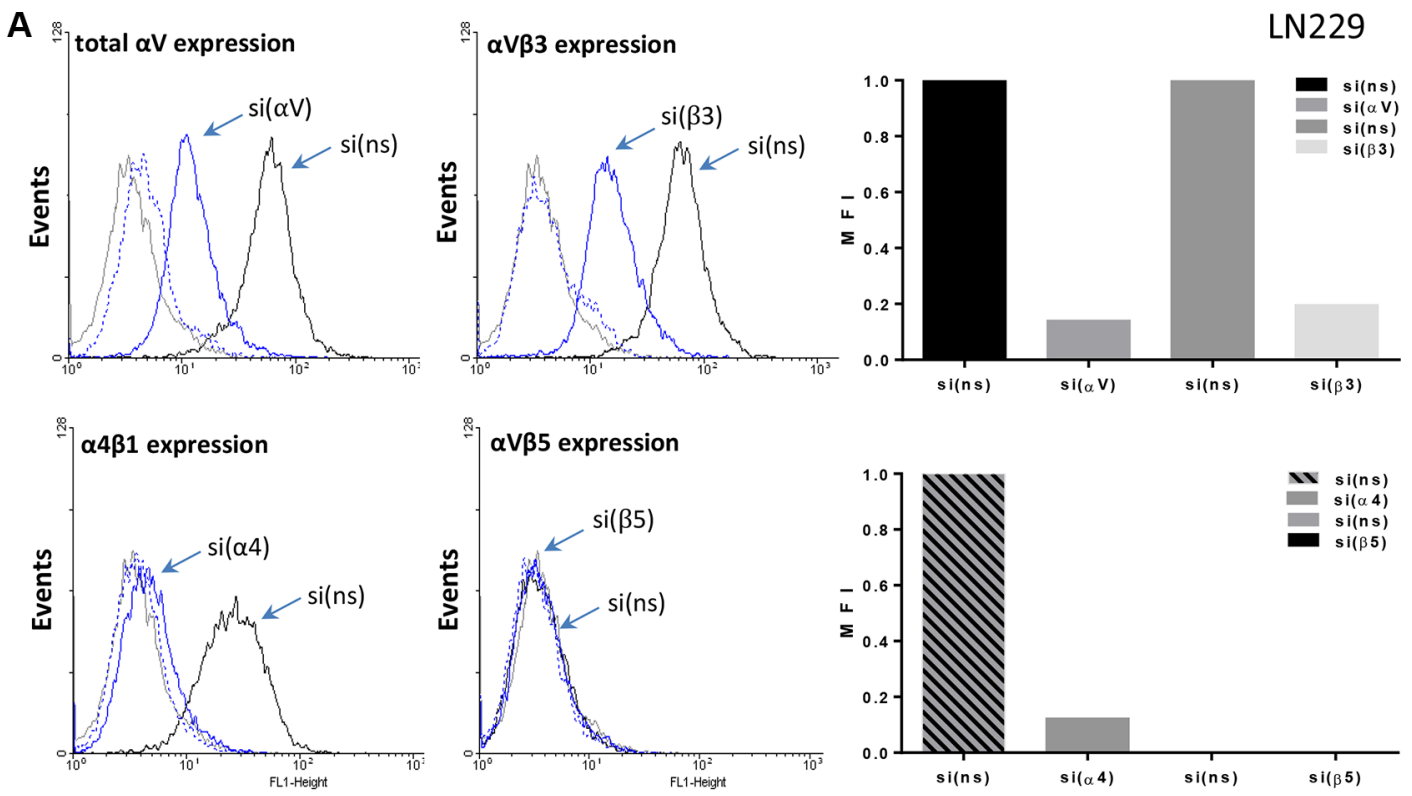

B
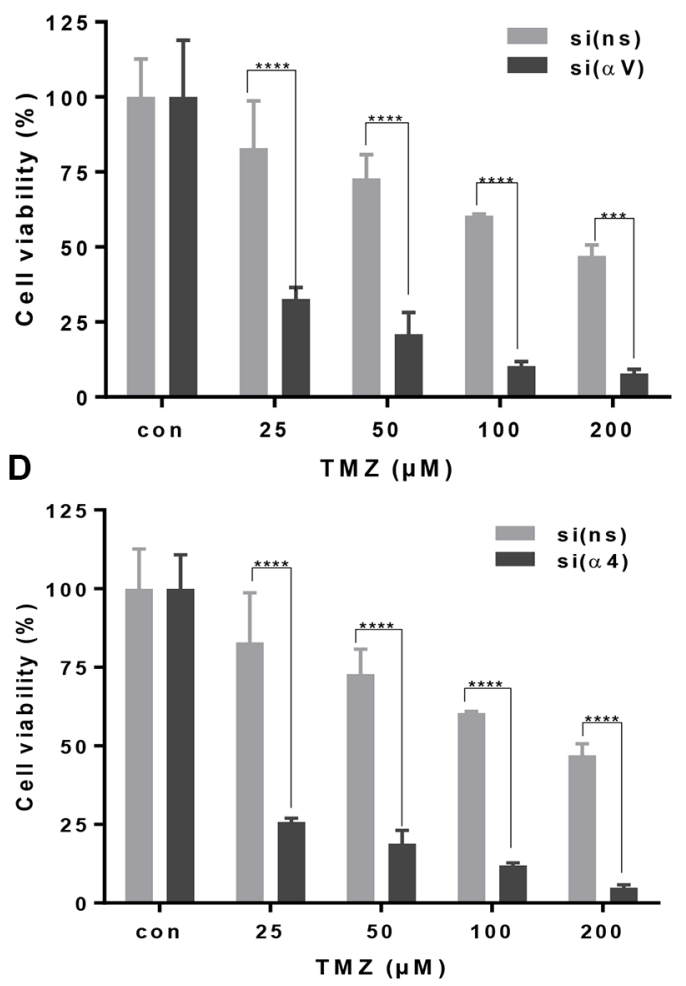

C
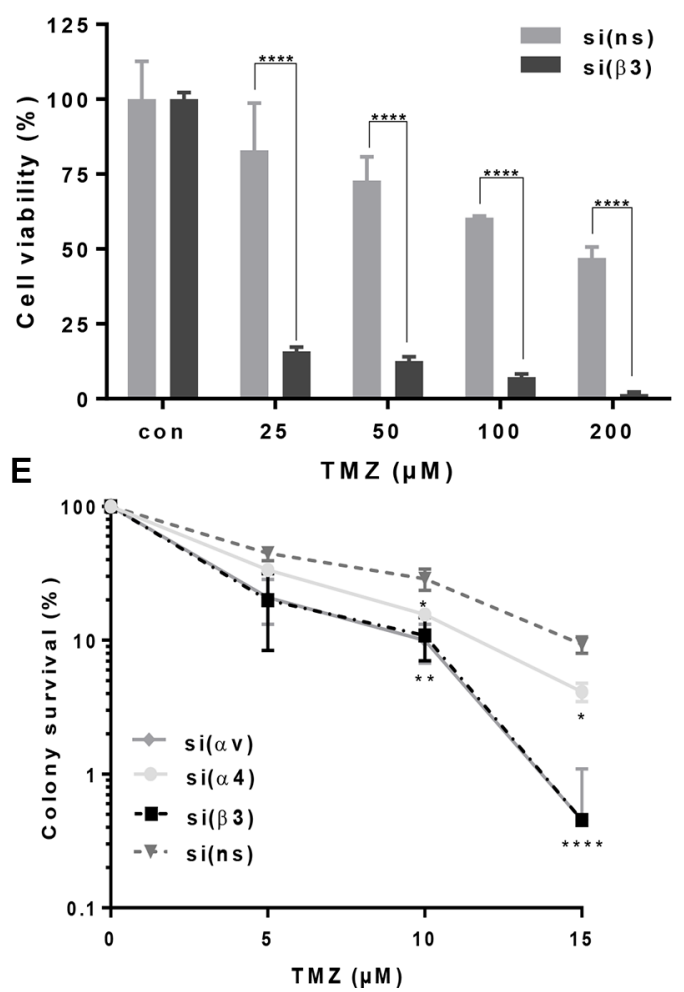

Figure 1: Integrin expression and sensitization to TMZ after specific integrin silencing. (A) LN229 cells were transfected with integrin $\alpha \mathrm{V}$-, $\alpha 4-, \beta 3$-, $\beta 5$-or control non-silencing (ns)-siRNA, $48 \mathrm{~h}$ later the cells were detached by EDTA and the expression of $\alpha \mathrm{V} \beta 3$, $\alpha \mathrm{V} \beta 5, \alpha \mathrm{V}$, and $\alpha 4 \beta 1$ was measured by flow cytometry. As a negative control, mouse IgG antibodies were used. The expression i.e. effective integrin silencing was quantified by mean fluorescence intensity (MFI) and represented as relative to expression in cells transfected with control non-silencing (ns)-siRNA that was set to 1 . The data presented are representative of three independent experiments with similar results. (B-D) LN229 cells were transfected with integrin $\alpha \mathrm{V}-, \alpha 4-, \beta 3-$, or ns-siRNA, and $24 \mathrm{~h}$ later collected by trypsinization and seeded for cell viability assay (MTT). After another $24 \mathrm{~h}$ the cells were treated with TMZ and after six days metabolic activity was assessed. The data are the mean of three independent experiments in quadruplicates \pm SD. (E) LN229 cells were seeded in 6-well cluster and $24 \mathrm{~h}$ later transfected with integrin $\alpha \mathrm{V}-, \alpha 4-, \beta 3$ - or ns-siRNA. After additional $24 \mathrm{~h}$ cells were re-seeded for colony formation assay at the density of 1000 cells per 6-well dish, and $24 \mathrm{~h}$ later exposed to TMZ or left unexposed. Fourteen days later the visible colonies were fixed, stained and counted. The plating efficiency of the cell lines after integrin silencing was $\sim 60-70 \%$. Unexposed integrin-specific and ns-control were set to $100 \%$. The data are the mean of three independent experiments \pm SD. ${ }^{*} p \leq 0.05$ significant, ${ }^{* *} p \leq 0.01$ very significant, ${ }^{* * *} p \leq 0.005$ highly significant, $* * * * p \leq 0.001$ most significant. 
Table 1: Integrin expression in malignant glioma cell lines

\begin{tabular}{|c|c|c|c|c|c|c|}
\hline Cell line & p53 status (rest activity) & MGMT activity (fmol/mg protein) & $\alpha 3 \beta 1$ & $\alpha 4 \beta 1$ & $\alpha v \beta 3$ & $\alpha v \beta 5$ \\
\hline T98MG & $\mathrm{mt}(0 \%)$ & $+(428)$ & - & + & + & + \\
\hline GBP61 & wt & $+(293)$ & + & + & + & + \\
\hline LN18 & $\operatorname{mt}(1 \%)$ & $+(205)$ & - & + & + & + \\
\hline LN229 & wt & $-(4)$ & - & + & + & - \\
\hline LN308 & mt (deletion) & $-(1)$ & - & + & + & $(+)$ \\
\hline LN319 & $\mathrm{mt}(1 \%)$ & $-(0)$ & + & $(+)$ & $(+)$ & + \\
\hline LN428 & $\mathrm{mt}(0 \%)$ & $-(0)$ & - & - & + & $(+)$ \\
\hline D247MG & wt & $-(19)$ & - & + & - & - \\
\hline U87MG & wt & $-(1)$ & - & - & + & + \\
\hline U138MG & $\mathrm{mt}(9 \%)$ & $-(2)$ & + & + & + & + \\
\hline
\end{tabular}

wt, wild-type; mt, mutant; “+"“, relative strong expression $(\mathrm{MFI}=0.4-1.0)$; “ $(+)$ “", relative weak expression $(\mathrm{MFI}=0.1-0.4)$; “_", no expression $(\mathrm{MFI}=0)$. Mean fluorescence intensity $(\mathrm{MFI})$ was set to 1 relative to the positive control $(\alpha \mathrm{V} \beta 3$ signal in GBP61 cells).

concentration of $100 \mu \mathrm{M} \mathrm{TMZ}$ was shown to be an optimal concentration in glioma cell culture experiments $[21,22]$ and is also achievable in the blood plasma. Integrin silencing sensitized cells to TMZ, as shown by the subG1 fraction, determined at 96, 120 and $144 \mathrm{~h}$ (for LN229 and U87MG, see Figure 2A-2D; for LN308 and U138MG, see Supplementary Figure S5A and S6A). The same was true using the annexin $\mathrm{V}$ assay, pointing to a specific induction of apoptosis, whereas the frequency of necrosis remained constant (for LN229 and U87MG, see Figure 3A, left panel). In support of this, increased activity of the executive caspase-3/7 was observed (for LN229 and U87MG, see Figure 3A, right panel; for LN308 and U138MG, see Supplementary Figure S7A, S7B, left panel). Of note, integrin silencing slowed down the cells in general but did not cause any significant changes in the cell cycle phase distribution (data not shown).

In order to elucidate whether the sensitization effect towards TMZ can also be achieved by administration of a cyclo-RGD inhibitor, we used an integrin antagonist that is similar to CGT. This inhibitor predominantly inhibits integrin $\alpha \mathrm{V} \beta 3$ and, albeit to a lower extent, $\alpha \mathrm{V} \beta 5$, thus the imposed effects can be primarily attributed to inhibition of $\alpha \mathrm{V} \beta 3$. As shown by the increased subG1 fractions all glioma cell lines were sensitized to TMZ, independent of their p53 status (Figure 2E, Figure 2F, Supplementary Figure S5B and Supplementary Figure S6B). The strongest inhibitor-mediated sensitization effect, in analogy to integrin $\beta 3$ and $\alpha \mathrm{V}$ knockdown, was achieved in LN229 cells (Figure 2E). The induction of apoptosis upon combination treatment with the cyclo-RGD inhibitor and TMZ was confirmed by the annexin $\mathrm{V}$ assay (Figure 3B, upper panel) and induction of the caspase-3/7 activity (Figure 3B, lower panel, Supplementary Figure S7A, S7B, right panel).

\section{Effect of $\alpha \mathrm{V} \beta 3$ silencing on the number of $\gamma H 2 A X$ foci upon TMZ exposure}

To investigate whether integrin signaling is associated with the DNA damage response and DNA repair, we determined the induction of $\gamma \mathrm{H} 2 \mathrm{AX}$ foci in integrin-silenced cells exposed to TMZ. We observed that the number of TMZ-induced $\gamma \mathrm{H} 2 \mathrm{AX}$ foci was enhanced by all integrin-specific siRNAs in LN229 cells (Figure 4A-4D) and U138MG cells (Supplementary Figure S8), indicating inefficient repair of DSBs. In unexposed controls, none of the siRNAs was able to induce $\gamma \mathrm{H} 2 \mathrm{AX}$ foci on its own. The repair foci were verified by co-localization of $\gamma \mathrm{H} 2 \mathrm{AX}$ and 53BP1 (data not shown). Since the sensitization to TMZ using either $\beta 3$ - or $\alpha$ V-siRNA in LN229 cells was comparable (see Figure 1B, $1 \mathrm{C}$ and $1 \mathrm{E}$ ), the increased number of $\gamma \mathrm{H} 2 \mathrm{AX}$ foci is likely caused by silencing of $\alpha \mathrm{V} \beta 3$ but the effect of $\alpha \mathrm{V} \beta 1$ cannot be excluded.

\section{Effect of $\alpha V \beta 3$ silencing on the number of Rad51 foci and HR efficiency upon TMZ exposure}

Since increased frequency of $\gamma \mathrm{H} 2 \mathrm{AX}$ foci pointed to a reduced DSB repair, we examined whether and to what extent the number of Rad51 foci is modulated by 
silencing of $\alpha \mathrm{V}$ or $\beta 3$ upon TMZ exposure. The data shows that the number of Rad51 foci constantly declined during the exposure time (48-96 h, Figure 5A) whereas the $\gamma \mathrm{H} 2 \mathrm{AX}$ foci remained at high level, indicating that HR was compromised. The number of Rad51 foci in LN229 cells after $\alpha \mathrm{V}$ or $\beta 3$ knockdown was dramatically reduced $96 \mathrm{~h}$ after TMZ exposure as compared to the number of foci at $48 \mathrm{~h}$. In contrast, the number of Rad51 foci in cells transfected with control-siRNA increased with time and was higher at 72 and $96 \mathrm{~h}$ in comparison to $48 \mathrm{~h}$ upon exposure to TMZ (see Figure 5A). Whereas all Rad51 foci co-localized with $\gamma \mathrm{H} 2 \mathrm{AX}$ foci in controlsiRNA transfected cells (indicating ongoing HR) upon integrin $\alpha \mathrm{V}$ and $\beta 3$ knockdown, a lot of $\gamma \mathrm{H} 2 \mathrm{AX}$ foci did not co-localize with Rad51, indicating persistent DSBs (Figure 5B). The results were supported by a significant
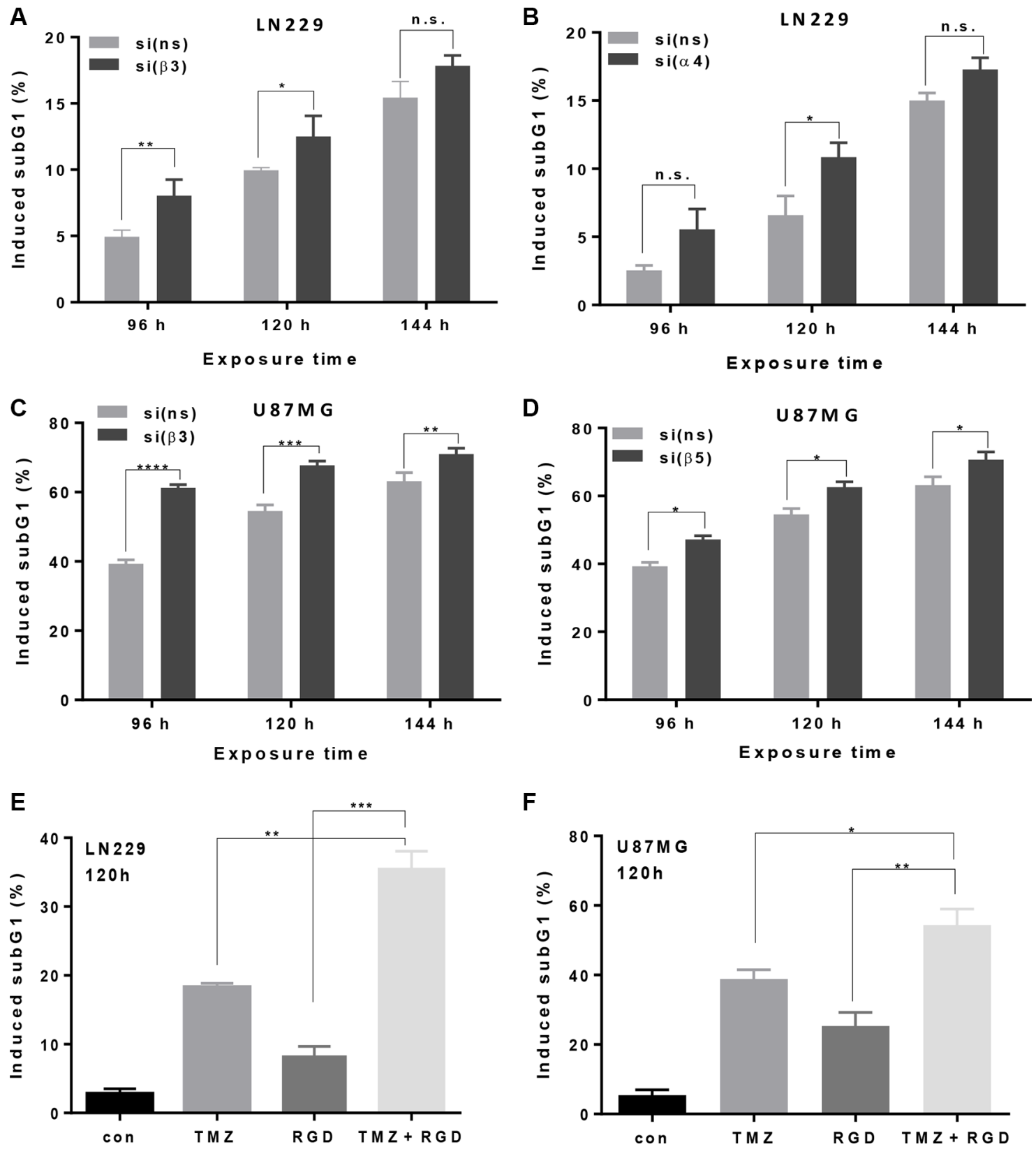

Figure 2: Modulation of apoptosis induction by integrin silencing or pharmacological inhibition. (A, B) LN229 and (C, D) U87MG cells were transfected with integrin $\beta 3-, \alpha 4-, \beta 5$ - or ns-siRNA, and $48 \mathrm{~h}$ later exposed to $100 \mu \mathrm{M} \mathrm{TMZ}$. After 96,120 and $144 \mathrm{~h}$ the cells were subjected to subG1 flow cytometric analysis. The data are the mean of two independent experiments in duplicates \pm SD. (E, F) LN229 and U87MG cells were pre-treated with a cyclo-RGD integrin antagonist $(10 \mu \mathrm{g} / \mathrm{mL})$ alone, or exposed, in addition, to $100 \mu \mathrm{M}$ TMZ. $120 \mathrm{~h}$ later, the cells were subjected to subG1 flow cytometric analysis. The data are the mean of two independent experiments in duplicates \pm SD. ${ }^{*} p \leq 0.05$ significant, $* * p \leq 0.01$ very significant, $* * * p \leq 0.005$ highly significant, $* * * * p \leq 0.001$ most significant. n.s., not significant. 

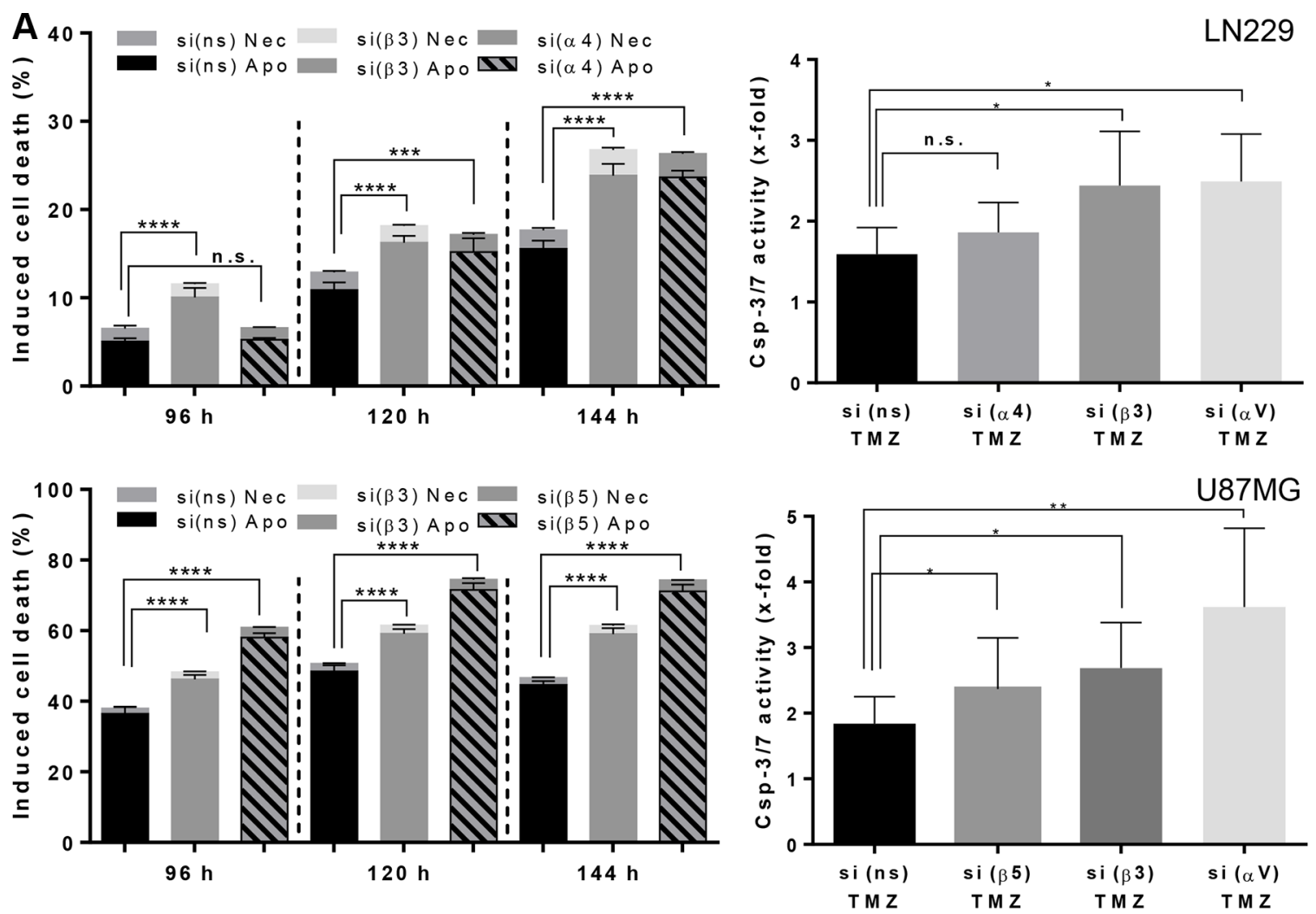

B
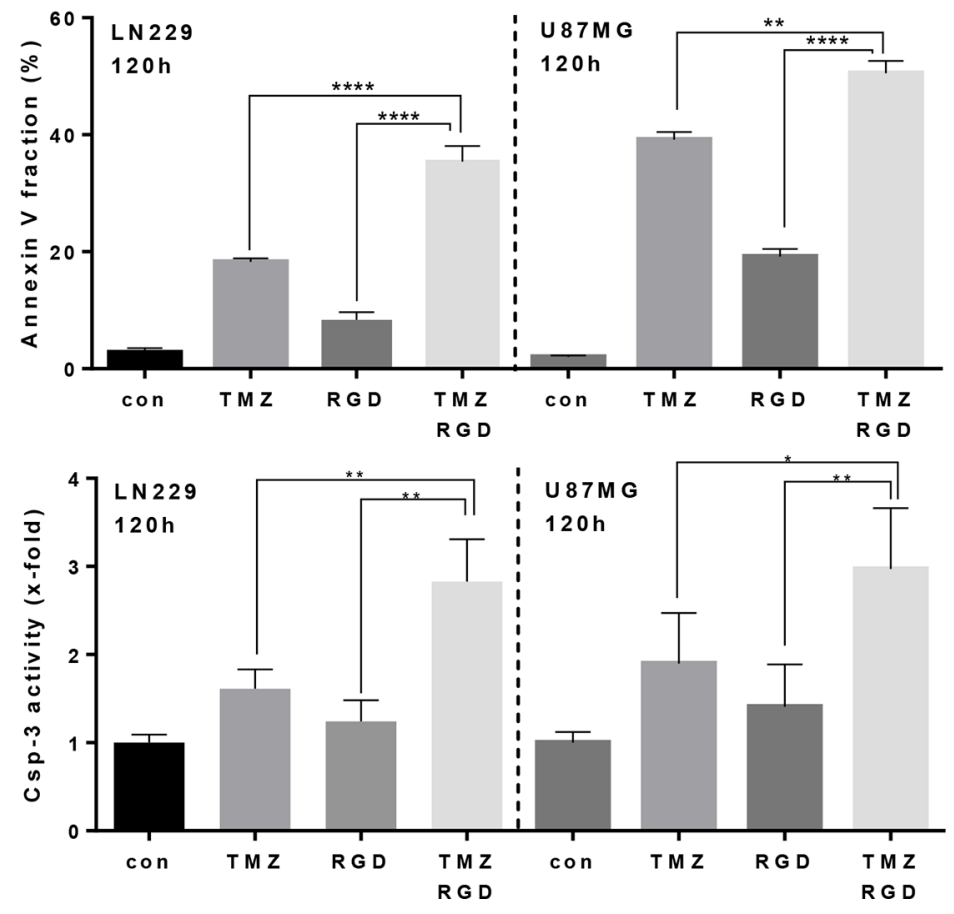

Figure 3: Induction of apoptosis/necrosis and caspase-3/7 activity. (A) (left panel): LN229 and U87MG cells were transfected with integrin $\beta 3-, \alpha 4-, \beta 5$ - or ns-siRNA, respectively, and $48 \mathrm{~h}$ later exposed to TMZ $(100 \mu \mathrm{M})$. After 96,120 and $144 \mathrm{~h}$ the cells were subjected to subG1 flow cytometric analysis. The data are the mean of two independent experiments in duplicates \pm SD. (A) (right panel): LN229 and U87MG cells were transfected with integrin $\beta 3-, \alpha 4-, \beta 5$ - or ns-siRNA, respectively, and $24 \mathrm{~h}$ later re-seeded in the 96-well plate. After additional $24 \mathrm{~h}$ cells were treated with TMZ $(100 \mu \mathrm{M})$ and $120 \mathrm{~h}$ later the caspase-3/7 activity was determined. (B) LN229 and U87MG cells were pre-treated with a cyclo-RGD integrin antagonist $(10 \mu \mathrm{g} / \mathrm{mL})$ alone, or exposed, in addition, to TMZ $(100 \mu \mathrm{M}) .120 \mathrm{~h}$ later, the cells were subjected to annexin V/PI staining and to caspase-3/7 analysis. The data are the mean of two independent experiments in duplicates \pm SD. ${ }^{*} p \leq 0.05$ significant, ${ }^{* *} p \leq 0.01$ very significant, ${ }^{* * *} p \leq 0.005$ highly significant, ${ }^{* * * *} p \leq 0.001$ most significant. n.s., not significant. 
reduction of HR efficiency in LN229 cells transfected with $\beta 3$-siRNA and treated with TMZ (Figure 4B, for qPCR melting curves, see Supplementary Figure S9).

\section{Reduction in the number of Rad51 foci is a consequence of $\alpha \mathrm{V} \beta 3$ integrin silencing}

In order to examine whether the reduced number of $\operatorname{Rad} 51$ foci is a consequence of integrin $\beta 3$ silencing, we utilized a cell clone with stable Rad51 knockdown (LN229-Rad51kd), which was shown to be hypersensitive to TMZ [23]. In this clone, the integrin subunit $\beta 3$ or $\alpha \mathrm{V}$ was silenced and cells were treated with a low TMZ concentration $(2.5-20 \mu \mathrm{M})$. As shown in Figure 6A-6B, neither silencing of $\beta 3$ nor $\alpha \mathrm{V}$ had impact on TMZ-induced cytotoxicity in the LN229-Rad51kd clone. There was also no difference in the induction of $\gamma \mathrm{H} 2 \mathrm{AX}$ foci in the LN229-Rad51kd clone upon $\beta 3$ knockdown (Figure 6C).
Conversely, the parental LN229 cells transfected with control-siRNA and exposed to $10 \mu \mathrm{M}$ TMZ were able to significantly repair DSBs, whereas the cells transfected with integrin $\beta 3$-siRNA were unable to do so, even at this low TMZ concentration (Figure 6D). Collectively, the data indicate that the increased TMZ cytotoxicity upon $\alpha \mathrm{V} \beta 3$ knockdown is due to a reduced Rad51-dependent repair of DSBs.

\section{Modulation of integrin signaling kinases and Rad51 expression by $\beta 3$ silencing and TMZ}

We also analyzed whether the signaling kinases FAK, Src and ILK are modulated upon $\beta 3$ knockdown. It is well known that tyrosine 397 of the FAK protein is the main target of autophosphorylation, which leads to the activation of FAK, and renders pFAK (Y397) as high-affinity partner for binding of Src [24]. Similarly,
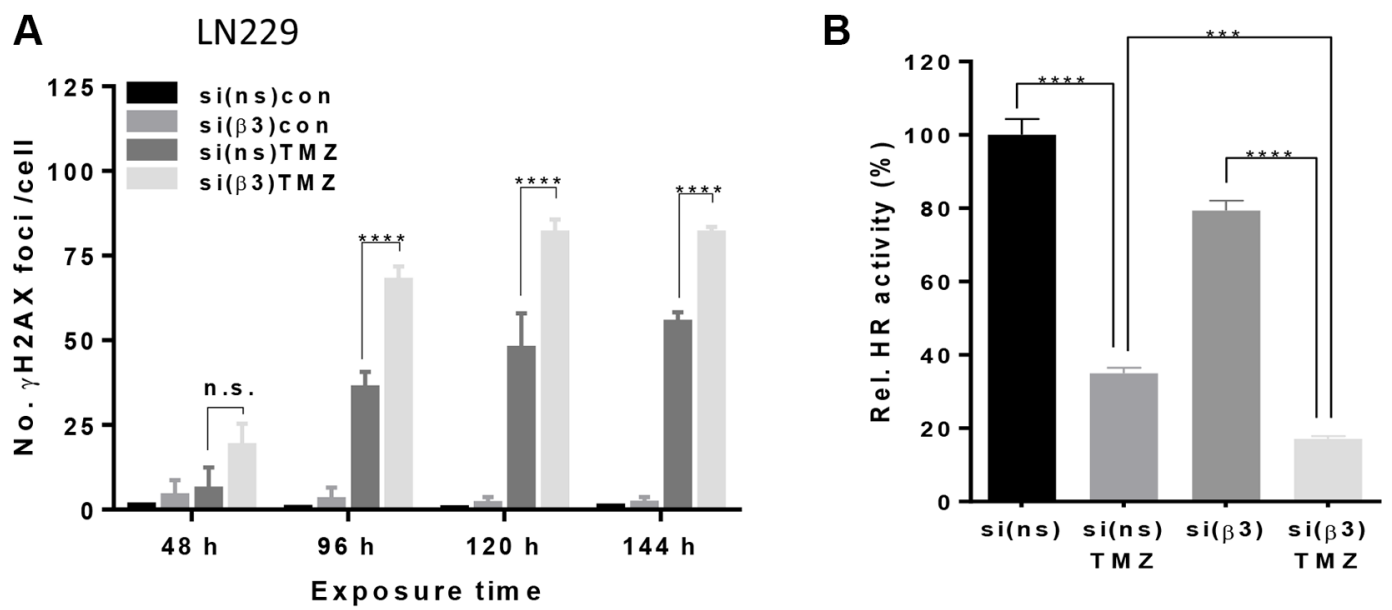

C

D
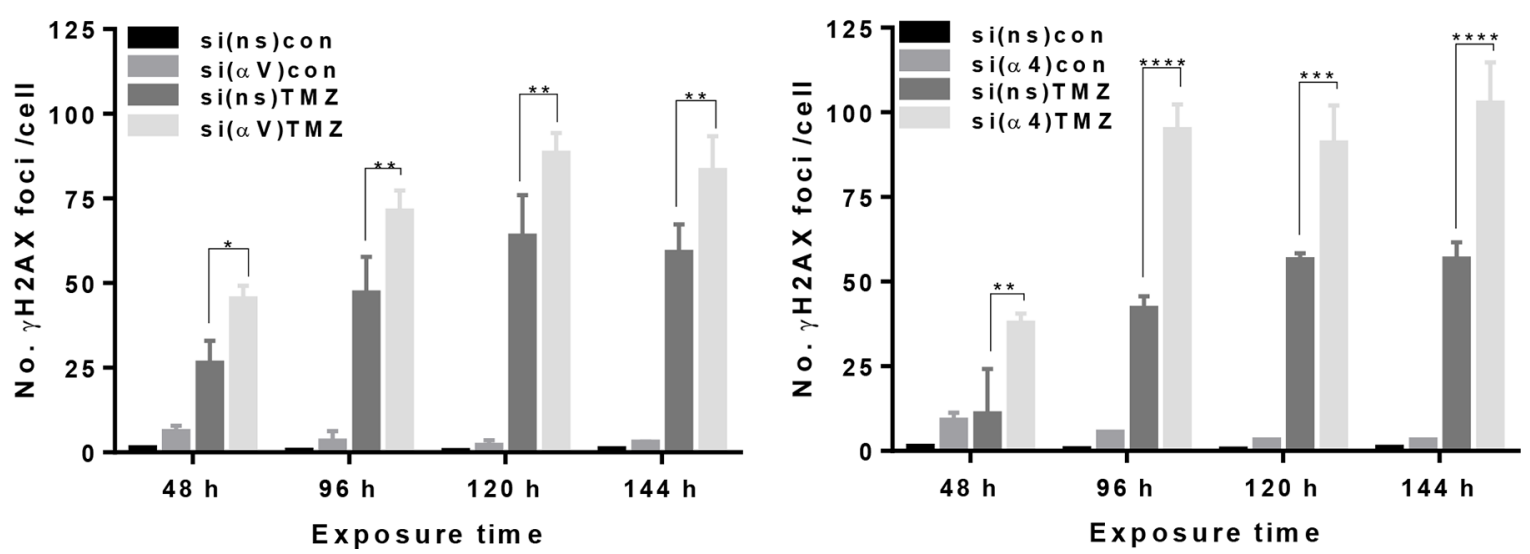

Figure 4: Induction of $\gamma \mathrm{H} 2 \mathrm{AX}$ foci upon TMZ/integrin silencing. (A, C, D) LN229 cells were transfected with $\beta 3-, \alpha \mathrm{V}-, \alpha 4-$ or ns-siRNA and exposed to $100 \mu \mathrm{M}$ TMZ. At indicated time points, the cells were stained for $\gamma \mathrm{H} 2 \mathrm{AX}$. Counterstaining of the nuclei was performed using TO-PRO-3. The data are the mean of two independent experiments in duplicates \pm SD. (B) Efficiency of homologous recombination (HR) after transfection of LN229 cells with control-siRNA or $\beta 3$-siRNA alone or combined with $100 \mu \mathrm{M}$ TMZ. Cellular DNA was extracted $96 \mathrm{~h}$ after TMZ exposure. Samples were standardized with universal primers, detecting the plasmid backbone for control of transfection efficiency. HR activity in control-siRNA transfected cells was set to $100 \%$. The data are the mean of two independent experiments in duplicates \pm SD. ${ }^{*} p \leq 0.05$ significant, ${ }^{*} p \leq 0.01$ very significant, ${ }^{* * *} p \leq 0.005$ highly significant, $* * * p \leq 0.001$ most significant. n.s., not significant. 
the autophosphorylation at Y418 is required for full catalytic activity of Src [25]. Another catalytic adaptor that directly binds the $\beta 1$ and $\beta 3$ integrin cytoplasmic tails is ILK [26]. The data show that pFAK and pSrc expression was reduced 24-96 h upon TMZ treatment (following $48 \mathrm{~h} 33$-siRNA transfection) (Figure 7A), while the expression of ILK was not changed (data not shown), indicating that integrin $\alpha \mathrm{V} \beta 3$ signals in glioma cells through pFAK and pSrc. In line with this, $\beta 3$ silencing also resulted in dephosphorylation of the prosurvival kinase Akt (Figure 7A). Most interestingly, TMZ exposure led to a reduction in Rad51 protein expression, but upon $\beta 3$ silencing the reduction was strongly enhanced and started even earlier i.e. $24 \mathrm{~h}$ after TMZ exposure. Reduction of Rad51 was due to proteasomal degradation (Figure 7B) and was most pronounced 120$144 \mathrm{~h}$ upon TMZ exposure and paralleled the H2AX phosphorylation (Figure 7C). Since Rad51 degradation was also observed in control-siRNA transfected cells, albeit to a much lower extent, this effect appears to result partially from TMZ itself, but is strongly amplified following $\beta 3$ silencing (Figure 7A, 7C).
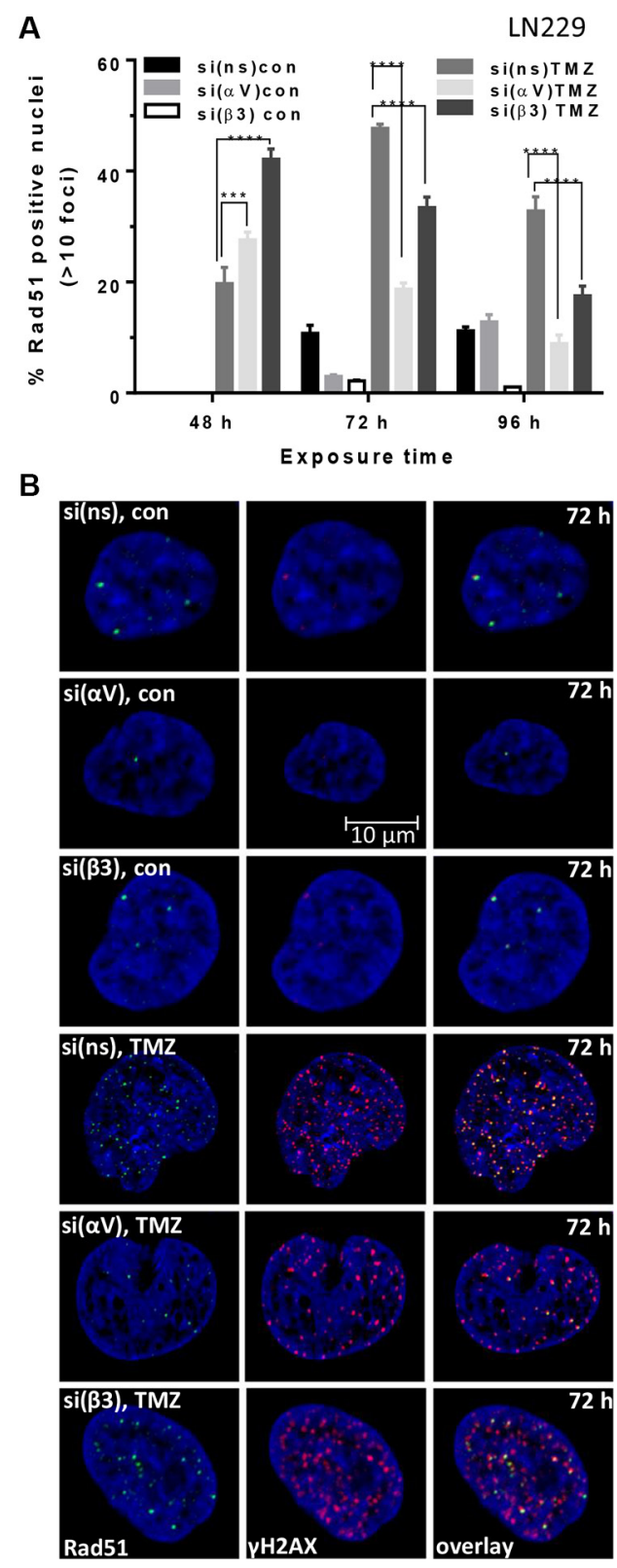

Figure 5: Induction of Rad51 foci upon TMZ/ $\alpha \mathrm{V} \beta 3$ integrin silencing. (A) LN229 cells were transfected with $\alpha \mathrm{V}-$, $\beta 3$ - or ns-siRNA and exposed to $100 \mu \mathrm{M}$ TMZ. At indicated time points, the cells were stained for Rad51 and $\gamma \mathrm{H} 2 \mathrm{AX}$. Counterstaining of the nuclei was performed using TO-PRO-3. The data are the mean of two independent experiments in duplicates \pm SD. $* p \leq 0.05$ significant, ${ }^{* *} p \leq 0.01$ very significant, ${ }^{* * *} p \leq 0.005$ highly significant, $* * * * p \leq 0.001$ most significant. n.s., not significant. (B) The representative nuclei at $72 \mathrm{~h}$ upon TMZ exposure showing co-localization (overlay) of Rad51 foci (green staining) and $\gamma \mathrm{H} 2 \mathrm{AX}$ foci (red staining). The nuclei were stained with TO-PRO-3 (blue staining). 


\section{Modulation of apoptosis pathways by $\beta 3$ silencing combined with TMZ}

It has been shown that dephosphorylation of Akt might be an important trigger of apoptosis through direct phosphorylation of X-linked inhibitor of apoptosis (XIAP) [27]. Indeed, following Akt dephosphorylation (Figure 7A) XIAP was proteasomally degraded (Figure 8A), which led to a subsequent degradation of survivin and $\mathrm{Bcl}-\mathrm{x}_{\mathrm{L}}$ (Figure 8A). Reduced expression of these anti-apoptotic proteins led to cleavage of caspase- 3 and reduction of its downstream target pro-caspase-2 (Figure 8A, left panel). Interestingly, the late activation of caspase-2 (120-144 h) coincided with reduction in RIP1 protein (Figure $8 \mathrm{~B}$, left panel), which is one of its putative targets [28]. In line with this, RIP1 kinase, although reduced in its protein level, was not proteasomally degraded (Figure 7B, right panel). RIP1 itself is a crucial factor for activation of $\mathrm{NF \kappa B}$ in DNA damage-induced apoptosis [29]. Moreover, I $\kappa \mathrm{B} \alpha$, the inhibitor of $\mathrm{NF} \kappa \mathrm{B}$, was found less degraded in $\beta 3$-siRNA than in controlsiRNA transfected cells upon TMZ treatment (Figure 7B), suggesting incomplete activation of $\mathrm{NF} \kappa \mathrm{B}$.
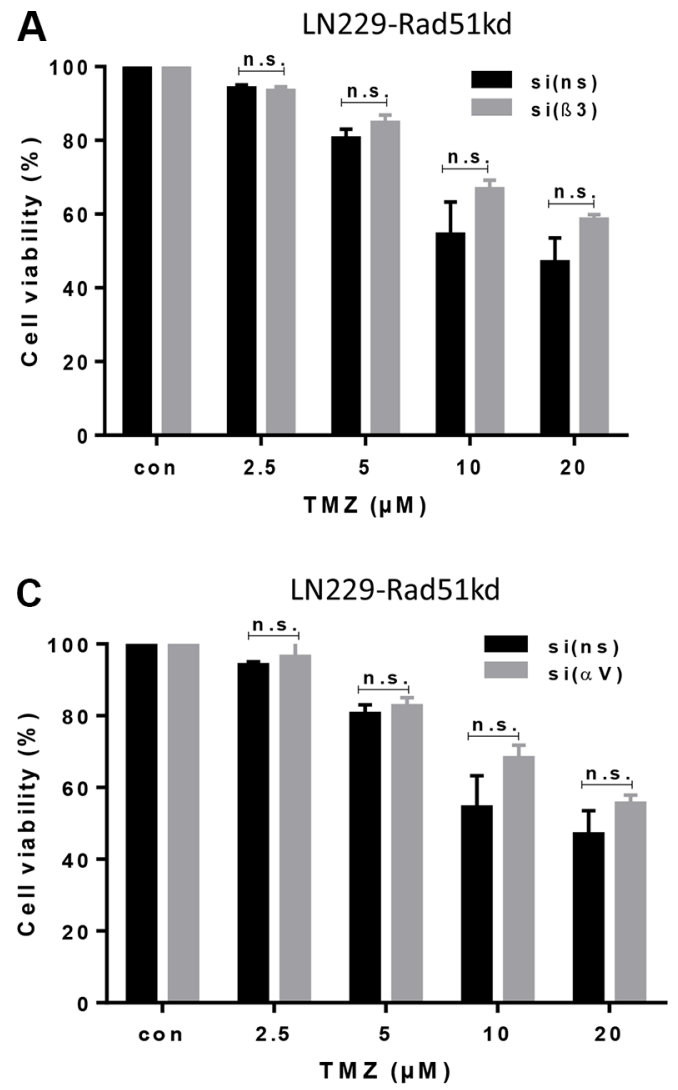

Reduction in NFKB activity by pharmacological inhibition or by integrin silencing reinforces reduction in Rad51 upon TMZ treatment

Recently it was shown that $\mathrm{NF} \kappa \mathrm{B}$ can directly support HR by binding to the BRCA1-CtiP complex, leading to a more efficient Rad51-dependent repair of DSBs [30]. Therefore, we analyzed whether incomplete activation of NFאB may influence Rad51 expression upon TMZ exposure. To this end, LN229 cells were exposed to $\mathrm{TMZ}$ and $24 \mathrm{~h}$ later treated with a specific inhibitor of NFкB. As shown in Figure 8C, 96 h upon TMZ exposure Rad51 protein expression was reduced, but the effect was significantly more pronounced following $\mathrm{NF \kappa B}$ inhibition. In line with this, the reporter assay showed a strongly reduced $\mathrm{NF} \kappa \mathrm{B}$ activity upon $\mathrm{TMZ} / \beta 3$ silencing (see Figure 8D). TMZ itself and TMZ/control-siRNA elevated NFKB activity, as reported [31]. Altogether, the data indicates the incomplete activation of $\mathrm{NF \kappa B}$ observed upon TMZ/ $\beta 3$ silencing could at late time points additionally decrease Rad51 expression and thus suppress HR activity.
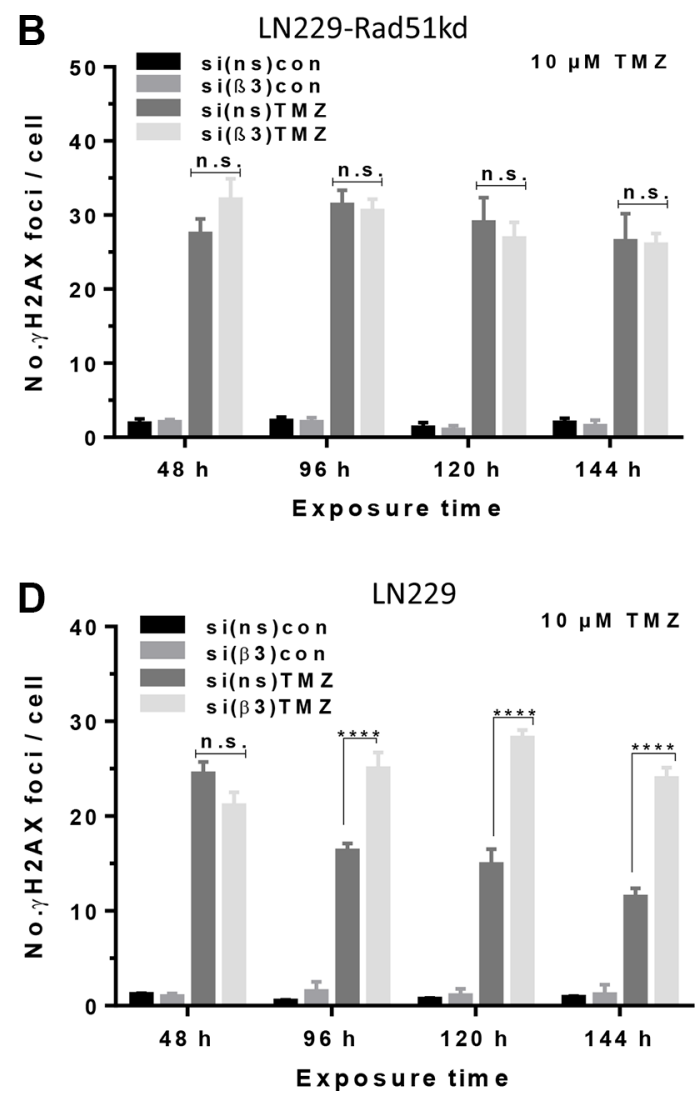

Figure 6: Determination of cell viability and induction of $\gamma \mathbf{H 2 A X}$ foci in Rad51 knockdown cells upon TMZ/ $\boldsymbol{\alpha V \beta 3}$ integrin silencing. (A, B) LN229-Rad51kd cells were transfected with $\alpha \mathrm{V}-, \beta 3-$, or ns-siRNA and $48 \mathrm{~h}$ later exposed to TMZ $(2.5-20 \mu \mathrm{M})$ for determination of cell viability in the metabolic MTT assay. (C) Time-dependent induction of yH2AX in LN229Rad51kd cells transfected with $\beta 3$-or ns-siRNA, non-exposed or exposed to $10 \mu \mathrm{M}$ TMZ. (D) Time-dependent induction of $\gamma \mathrm{H} 2 \mathrm{AX}$ foci in LN229 cells transfected with $\beta 3$ - or ns-siRNA, non-exposed or exposed to $10 \mu \mathrm{M}$ TMZ. The data are the mean of two independent experiments in duplicates $\pm \mathrm{SD} .{ }^{*} p \leq 0.05$ significant, ${ }^{* *} p \leq 0.01$ very significant, $* * * p \leq 0.005$ highly significant, $* * * * p \leq 0.001$ most significant. n.s., not significant. 


\section{Verification of in vitro data in xenograft model in vivo}

To verify the molecular mechanism in vivo and to demonstrate that inhibition of integrin signaling has impact on DNA repair and the cytotoxic response of glioma cells to TMZ, we treated nude mice bearing U87MG tumor xenografts with the cyclo-RGD inhibitor and challenged them with TMZ. As shown in Figure 9A, expression of $\gamma \mathrm{H} 2 \mathrm{AX}$ and cleaved caspase-3, as well as reduction in Rad51 and RIP1 expression and sustained level of IкB $\alpha$ expression were significantly more enhanced in tumor extracts from animals treated with the inhibitor and TMZ, in comparison to non-treated mice and mice treated with the RGD inhibitor or TMZ only, revealing the same molecular mechanism to occur also in vivo. Similar to in vitro results, inhibition of $\alpha \mathrm{V} \beta 3$ by the RGD inhibitor enhanced the TMZ response and furthermore triggered tumor regression (examples are shown in Figure 9B).

\section{Effect of integrin $\alpha \mathrm{V}$ silencing on migration of glioma cells}

In order to substantiate the decisive role of integrins $\alpha \mathrm{V}$ as feasible targets not only for sensitization to alkylation-based glioma therapy in terms of induction of apoptosis but also to combat metastasis, we conducted migration assays. We observed that upon knockdown of different integrins in LN229 (Figure 10A) and U138MG (Figure 10B) cells migration was significantly decreased, but the most dramatic effect was observed in LN229 cells upon $\alpha \mathrm{V}$ knockdown. A similar highly potent effect

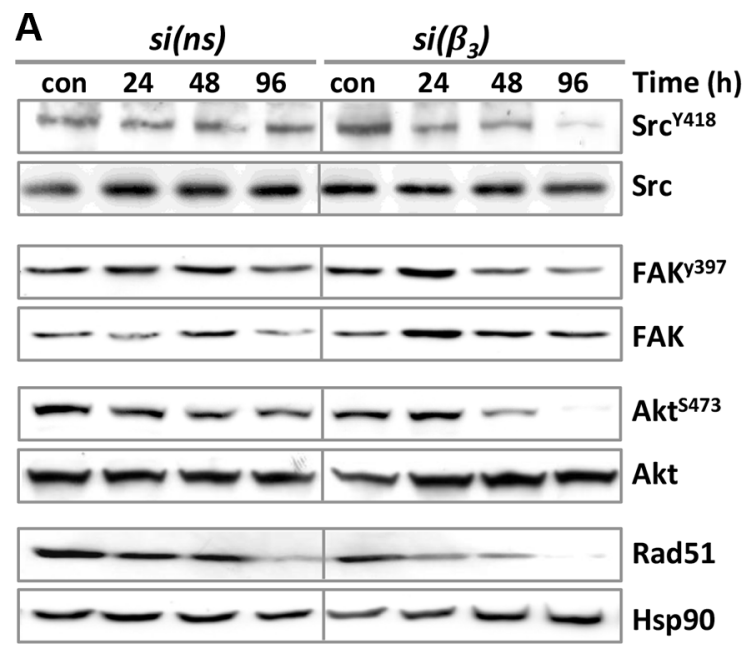

of integrin $\alpha \mathrm{V}$ knockdown was observed in U138MG cells, reflecting the involvement of both $\alpha \mathrm{V} \beta 3$ and $\alpha \mathrm{V} \beta 5$ in migration. In U138MG cells the $\beta 3$ knockdown inhibited migration significantly more efficient than knockdown of $\beta 5$, suggesting again that integrin $\alpha \mathrm{V} \beta 3$ is a potential therapeutic target for inhibition of metastasis. The knockdown of $\alpha 4$ in U138MG cells significantly inhibited migration but in LN229 cells did not affect migration at all.

\section{DISCUSSION}

Some integrin-targeting strategies like monoclonal antibodies and small molecules as CGT, which was shown to inhibit the activation of integrins $\alpha \mathrm{V} \beta 3$ and $\alpha \mathrm{V} \beta 5$ in the orthotopic brain model thereby inhibiting angiogenesis [11] have been tested in clinical trials [6]. It has been shown that $\alpha \mathrm{V}$ antagonists inhibit cancer growth independent of the anti-angiogenic effect [32]. Co-delivery of siRNAs with anticancer agents provides promising option for an improved chemotherapeutic effect. Various nanocarriers, which are not devoid of limitations, have been developed to deliver siRNA and drugs. The major challenge for siRNA-based therapeutics includes minimizing the potential off-target effects and controlling the specificity of the siRNA. However, it is anticipated that the research on combination delivery of siRNA and chemotherapeutics will progress with increase in the knowledge and innovative delivery strategies [33].

Although in a phase I/II study CGT had a beneficial effect for patients having tumors with MGMT promoter methylation [13], this positive curative effect was not

B
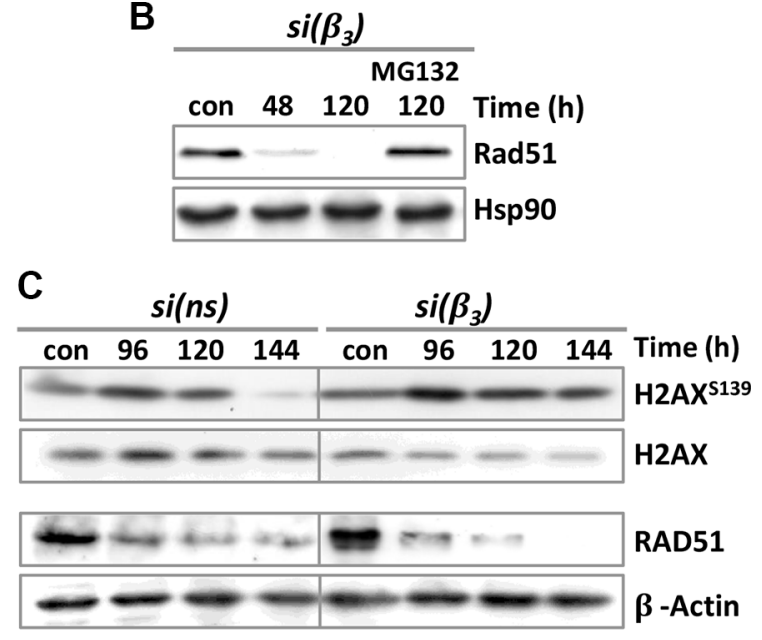

Figure 7: Expression of integrin signaling kinases, DNA repair proteins and apoptotic factors upon TMZ/ $\mathrm{TV} \beta 3$ integrin silencing. (A, B) LN229 cells were transfected with control-siRNA (si(ns)) or $\beta 3$-siRNA (si( $\beta 3)$ ) and 48 h upon transfection exposed to $100 \mu \mathrm{M}$ TMZ. A. At different time points (24-96 h) upon TMZ exposure, whole-cell extracts were isolated and subjected to western blot analysis of $\mathrm{pSrc}^{\mathrm{Y} 418}, \mathrm{Src}, \mathrm{pFAK}^{\mathrm{Y} 397}, \mathrm{FAK}, \mathrm{pAkt}^{\mathrm{S} 473}$, Akt and Rad51. B. The proteasomal inhibitor MG132 (10 $\left.\mu \mathrm{M}\right)$ was not added or added to the cells $24 \mathrm{~h}$ after addition of TMZ, and protein extracts examined for expression of Rad51 (con: TMZ-unexposed cells). Hsp90 was used as loading control. (C) LN229 cells were transfected with si(ns) or si( $\beta 3$ ) and $48 \mathrm{~h}$ later exposed to $100 \mu \mathrm{M}$ TMZ. The cells were collected at 96-144 h upon TMZ exposure and subjected to western blot analysis of unphosphorylated and phosphorylated $\mathrm{H} 2 \mathrm{AX}(\gamma \mathrm{H} 2 \mathrm{AX})$ and $\operatorname{Rad} 51 . \beta$-actin was used as loading control. 
confirmed in the phase III (CENTRIC) study [14]. In our opinion, the failure of the study could be explained by the CGT pharmacokinetics. In the CENTRIC study, CGT was applied as anti-angiogenic drug and probably poorly reached the tumor. In this context, it is important to note that the effectiveness of anti-integrin drugs was critically assessed before [34]. Thus, it was shown that a too low antagonist concentration instead of inhibiting, promotes angiogenesis [35]. Another reason for the failure might be the opposite action of radiotherapy and CGT. It was shown that IR induces expression of $\alpha \mathrm{V} \beta 3$ in human endothelial [32] and glioma cells [36]. If this is the case, concurrent integrin antagonists may be beneficial only in a TMZ mono-therapy setting. In spite of the negative outcome of the CENTRIC and CORE study, the data suggests that integrins remain an attractive target for cancer therapy.

Based on the data obtained in a panel of ten glioblastoma cell lines and the fact that $\alpha \mathrm{V} \beta 3$ represents the most frequently expressed integrin heterodimer on malignant gliomas [37], we focused on its impact on
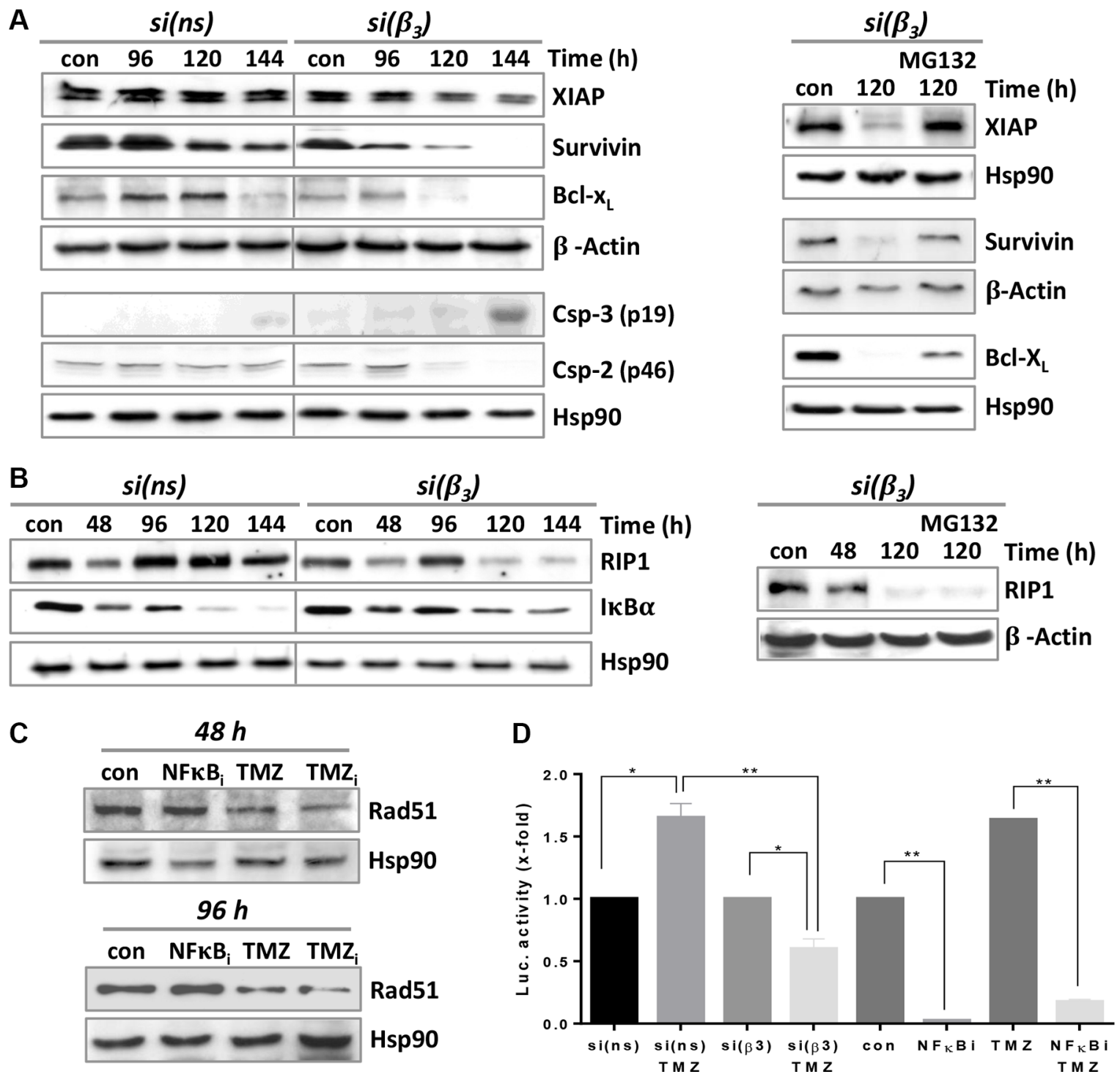

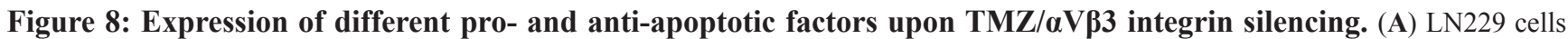
were transfected with integrin $\beta 3$ - or ns-siRNA and $48 \mathrm{~h}$ upon transfection exposed to $100 \mu \mathrm{M} \mathrm{TMZ}$ (left panel) or additionally exposed to MG132 $(10 \mu \mathrm{M}) 24 \mathrm{~h}$ after begin of TMZ treatment (right panel). The cells were collected 96-144 h after TMZ exposure and subjected to western blot analysis of XIAP, survivin, Bcl- $\mathrm{x}_{\mathrm{L}}$ and caspase-3/caspase-2 expression. $\beta$-actin and Hsp90 were used as loading control. (B) LN229 cells were transfected with integrin $\beta 3$ - or ns-siRNA and $48 \mathrm{~h}$ later exposed to $100 \mu \mathrm{M} \mathrm{TMZ}$ (left panel) or additionally exposed to MG132 $(10 \mu \mathrm{M}) 24 \mathrm{~h}$ after begin of TMZ treatment (right panel). The cells were collected at different times upon TMZ exposure and

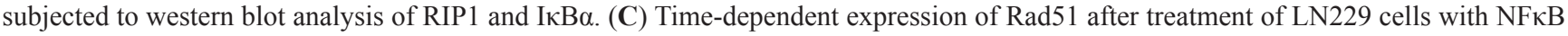

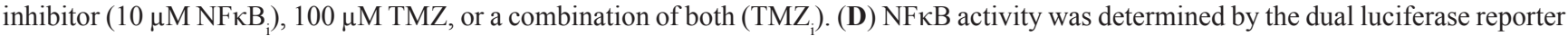
assay. Cell lysates were analyzed in triplicates and standardized for transfection using a renilla luciferase construct. The unexposed controls (con, si(ns), si( $(\beta 3))$ were set to 1 . NFkB $\mathrm{i}_{\mathrm{i}} \mathrm{NF \kappa B}$ inhibitor $(10 \mu \mathrm{M})$. The data are the mean of two independent experiments in duplicates \pm SD. ${ }^{*} p \leq 0.05$ significant, ${ }^{* *} p \leq 0.01$ very significant, ${ }^{* * *} p \leq 0.005$ highly significant, ${ }^{* * * *} p \leq 0.001$ most significant. 
TMZ-induced cytotoxicity and repair in vitro and in vivo. Moreover, the expression of $\alpha \mathrm{V} \beta 3$ in tumor cells and vessels, but not of other $\alpha \mathrm{V}$ integrins, was shown to be dependent on tumor grade, and $\alpha \mathrm{V} \beta 3$ expression in tumor cells may have a prognostic impact [38]. We could show that silencing of all of the respective integrin subunits $(\alpha \mathrm{V}$, $\alpha 3, \alpha 4, \beta 3$ and $\beta 5$ ) sensitized glioblastoma cell lines to $\mathrm{TMZ}$ but the silencing of $\alpha \mathrm{V} \beta 3$ was the most powerful. Moreover, cytotoxicity of TMZ was also enhanced in glioblastoma cell lines using a cyclo-RGD antagonist, which inhibits integrin $\alpha \mathrm{V} \beta 3$ comparably to CGT but needs much higher concentrations to antagonize $\alpha \mathrm{V} \beta 5$. Since the applied concentrations were rather low, we suppose that the sensitizing effect of the inhibitor is primarily attributed to silencing of $\alpha \mathrm{V} \beta 3$. The decisive role of integrins $\alpha \mathrm{V}$ for glioma therapy response was corroborated by decreased migration after their knockdown in LN229 and U138MG cells, thus indicating decreased metastatic potential. In LN229 cells the effect of integrin $\alpha \mathrm{V}$ knockdown was the most dominant, indicating that not only integrin $\alpha \mathrm{V} \beta 3$, but very likely also integrin $\alpha \mathrm{V} \beta 1$ is involved in cell migration. A similar highly potent effect of integrin $\alpha \mathrm{V}$ knockdown was observed in U138MG cells, reflecting the involvement of several $\alpha \mathrm{V}$ integrin heterodimers in migration, i.e. at least $\alpha \mathrm{V} \beta 3$ and $\alpha \mathrm{V} \beta 5$. In U138MG cells the $\beta 3$ knockdown inhibited migration significantly more efficient than knockdown of $\beta 5$, suggesting again that integrin $\alpha \mathrm{V} \beta 3$ is not only a potential therapeutic target for sensitization to TMZ but also for inhibition of metastasis.

Our results show that silencing of the integrins $\alpha 3 \beta 1, \alpha 4 \beta 1, \alpha \mathrm{V} \beta 3$ and $\alpha \mathrm{V} \beta 5$ strongly enhanced the TMZ-induced formation of DSBs, as determined by $\gamma \mathrm{H} 2 \mathrm{AX}$ foci induction. This was accompanied by a significantly reduced expression of the $\operatorname{Rad} 51$ protein due to proteasomal degradation, leading to a decline in the Rad51 foci level. Rad51 represents a rate-limiting factor for repair of TMZ-induced DSBs by HR [23].
Indeed, LN229 cells showed a decreased HR efficiency, indicating that decreased expression of $\operatorname{Rad} 51$ abrogates the repair of DSBs. This conclusion is further supported by the finding that $\beta 3$ silencing was neither able to further sensitize Rad51 knockdown cells to low-dose TMZ nor to enhance the number of TMZ-induced $\gamma \mathrm{H} 2 \mathrm{AX}$ foci. Thus suppression of DSB repair upon $\beta 3$ silencing equals the effect of a direct Rad51 inhibition which is in line with literature data [39]. As expected, inhibition of $\alpha \mathrm{V} \beta 3$ by the cyclo-RGD antagonist in combination with TMZ in the glioma xenograft model, led to pronounced tumor regression and showed consistently reinforced $\gamma \mathrm{H} 2 \mathrm{AX}$ phosphorylation and caspase-3 cleavage, strongly reduced Rad51 and RIP1 expression, and revealed a persistent $\mathrm{I} \kappa \mathrm{B} \alpha$ expression in tumors in situ compared to mice treated with TMZ alone. Thus, the data obtained in cell culture and in vivo reveals a very similar molecular mechanism, showing that inhibition of $\alpha \mathrm{V} \beta 3$ affects the DNA repair capacity and ameliorates the cytotoxic response of glioma cells to TMZ.

The proteasomal degradation of $\operatorname{Rad} 51$ seems to be an important mechanism in sensitizing cancer cells by suppressing HR $[40,41]$. In our hands, the efficiency of non-homologous end-joining upon TMZ/ $\beta 3$ silencing was not affected, as shown by the radioactive DNA-PKcs activity assay (Supplementary Figure S10), contrary to the published data for IR/ $\beta 1$ silencing [42]. Upon $\mathrm{TMZ} / \beta 3$ silencing we observed a modest slow-down in progression of cells in all phases of the cell cycle, as already mentioned. Nevertheless, we cannot exclude that this moderate arrest in S- and G2-phase contributes to the decreased Rad51 levels and impairment of HR.

Integrin-mediated adhesion modulates the expression of proteins like PI3K/Akt, Bad, Bcl-2, Bcl- $\mathrm{x}_{\mathrm{L}}$, survivin, XIAP, p27 Kip, and activation of MAP kinase pathways, activation of PARP and NFkB [43]. Thus, we further analyzed which signaling pathways and apoptotic factors are altered upon integrin silencing. Our data
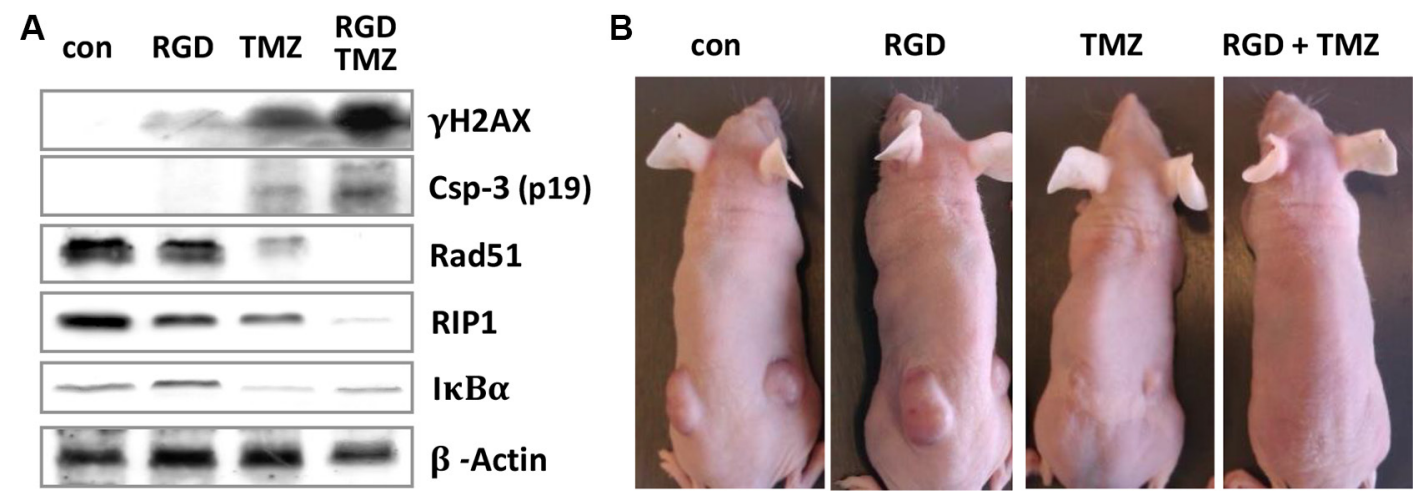

Figure 9: Expression of DNA repair and apoptotic factors in mice xenografts. (A) Nude mice (Balb/c nu/nu, two animals per each group) with U87MG xenografts were left untreated (con) or intraperitoneally injected with cyclo-RGD integrin antagonist (RGD), $\mathrm{TMZ}$, or a combination of both (RGD+TMZ). After regression time of three weeks, tumors were removed, proteins extracted and subjected to western blot analysis of $\gamma \mathrm{H} 2 \mathrm{AX}$, Rad51, RIP1, IкB $\alpha$ and cleaved caspase-3. $\beta$-actin was used as loading control. (B) Representative images of the nude mice, showing regression of tumors in TMZ- and RGD/TMZ-treated animals. 
revealed that integrin $\alpha \mathrm{V} \beta 3$ transmits signals through pFAK, pSrc and pAkt, which is in line with results showing that Src silencing enhanced the cytotoxic effect of TMZ in LN229 cells [44]. The same inhibition of FAK/Src/Akt in glioma cells was also shown upon CGT [45]. In our experiments $\beta 3$ silencing led to reduction in phosphorylation and expression of XIAP, which is presumably associated with the observed inactivation (dephosphorylation) of Akt [27]. The reduced expression of XIAP was also a result of proteasomal degradation and was associated with reduced expression of survivin, an essential mitotic and anti-apoptotic protein, which can be marked for degradation by the E3 ubiqutin ligase activity of XIAP [46]. Furthermore, we observed a reduced expression of the anti-apoptotic Bcl- $\mathrm{x}_{\mathrm{L}}$ protein, which might be explained through abrogation of Bad phosphorylation by Akt. In this case hypophosphorylated
Bad could deliberate $\mathrm{Bcl}-\mathrm{x}_{\mathrm{L}}$ from the complex allowing $\mathrm{Bcl}-\mathrm{X}_{\mathrm{L}}$ degradation [27]. $\mathrm{TMZ} / \beta 3$ silencing finally led to activation of caspase- 3 and a late decline in the level of pro-caspase-2, a known downstream target of caspase- 3 [47]. The activation of caspase- 2 coincided with reduction in RIP1, which is a crucial factor for activation of NFKB in DNA damage-induced apoptosis [29, 48]. Since reduction in RIP1 expression could not be inhibited by the MG132 proteasomal inhibitor, it might be a result of a direct cleavage by caspase-2, for which RIP1 was postulated to be a putative target [28]. Involvement of caspase- 8 in RIP1 cleavage could be excluded since caspase- 8 was not activated in our model (data not shown). In addition to reduced RIP1 expression at late time points, I $\kappa \mathrm{B} \alpha$ was stabilized upon TMZ/ $\beta 3$ silencing. Both, downregulation of RIP1 and enhanced stability of $\mathrm{I} \kappa \mathrm{B} \alpha$ may lead to incomplete activation of $\mathrm{NF} \kappa \mathrm{B}$ at late time points,
A

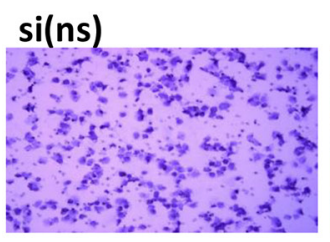

si $(\alpha V)$

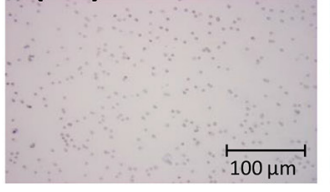

B
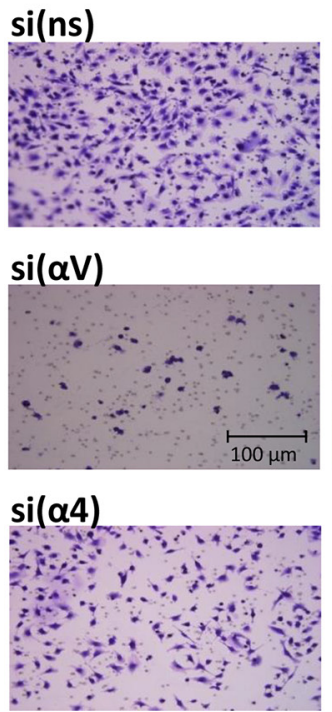
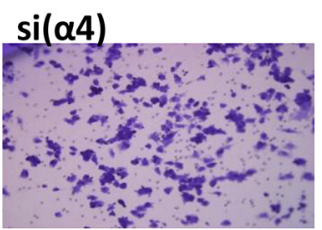

si(ß3)

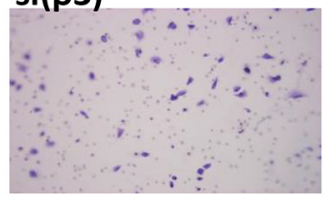

si(a3)

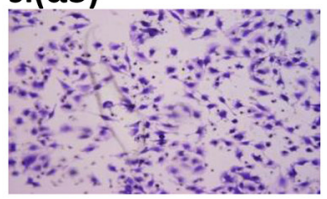

$\operatorname{si}(\beta 3)$

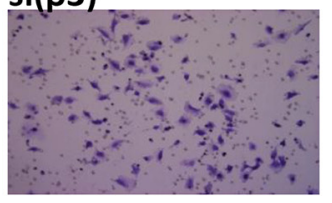

si(B5)

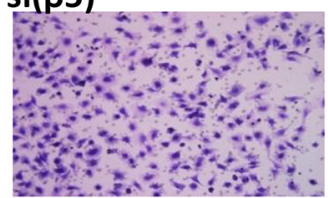

LN229

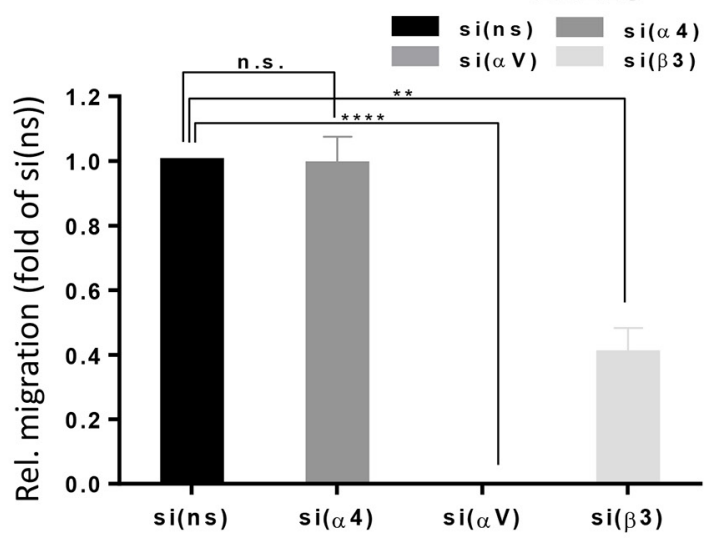

\section{U138MG}

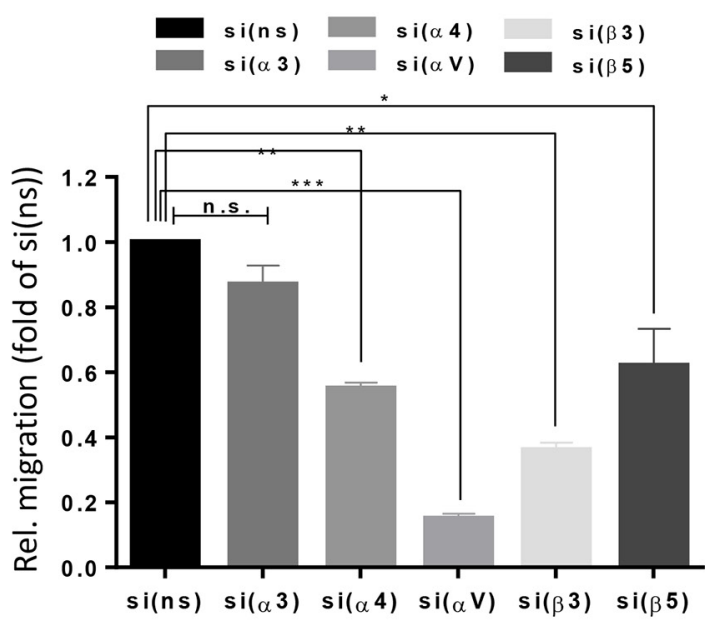

Figure 10: Integrin subunit knockdown decreases migration. Cell migration was determined in (A) LN229 cells upon transfection with control-, $\alpha 4-, \alpha \mathrm{v}$ - or $\beta 3$-siRNA and (B) U138MG cells upon transfection with control-, $\alpha 3-, \alpha 4-, \alpha \mathrm{v}-, \beta 5-$ or $\beta 3$-siRNA. $48 \mathrm{~h}$ after transfection, the cells were starved for $24 \mathrm{~h}$ and cell migration was measured in Boyden chambers. After $22 \mathrm{~h}$, cells on the underside of the membrane were stained with crystal violet, photographed and counted. Averages of five microscope fields \pm SD are shown. ${ }^{*} p \leq 0.05$ significant, ${ }^{* *} p \leq 0.01$ very significant, ${ }^{* * *} p \leq 0.005$ highly significant, $* * * * p \leq 0.001$ most significant. 
as supported by reduced $\mathrm{NF} \kappa \mathrm{B}$ activity in the reporter assay. NF $\kappa \mathrm{B}$ can act as a pro-survival transcription factor

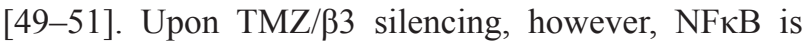
unlikely to be involved in the transcriptional regulation of $B c l-x_{\mathrm{L}}$, survivin and XIAP, since these factors were degraded by the proteasome. Besides being a transcription factor, $\mathrm{NF} \kappa \mathrm{B}$ can play a direct role in $\mathrm{HR}$ repair, stimulating Rad51 activity. In this case, $N F \kappa B$ regulates repair of DSBs in conjunction with BRCA1-CtiP complex [30] which might also be the case upon TMZ/ $\beta 3$ silencing. This assumption was further supported by the observation

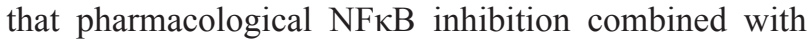
TMZ accelerated the Rad51 degradation, in comparison to $\mathrm{TMZ}$ alone (see Figure $7 \mathrm{C}$ ). Thereby NFкB inhibition recapitulates the effect of $\beta 3$ silencing on the $\operatorname{Rad} 51$ expression. However since Rad51 degradation was observed prior to the impairment of the $\mathrm{NF \kappa B}$ function following $\beta 3$ silencing, reduced $\mathrm{NF} \kappa \mathrm{B}$ activity cannot be the initial trigger. It is conceivable, however, that it suppresses Rad51 expression and HR activity at late time points, thereby amplifying the TMZ cytotoxicity.

Overall the present study shows that inhibition of the integrin $\alpha \mathrm{V} \beta 3$ sensitizes glioma cells to TMZ, altering multiple molecular pathways like DNA repair, signaling and apoptosis. Thus $\alpha \mathrm{V} \beta 3$ targeting combined with TMZ is a valuable approach to improve TMZ therapy of malignant gliomas.

\section{MATERIALS AND METHODS}

\section{Ethics statement}

Investigation has been conducted in accordance with the ethical standards and according to the Declaration of Helsinki and according to national and international guidelines and has been approved by the authors' institutional review board.

\section{Cell culture}

The human glioblastoma cell line U87MG was purchased from Cell Line Service (Eppelheim, Germany), and the glioblastoma cell line LN229 was obtained from LGC Standards (Wesel am Rhein, Germany). The glioblastoma cell lines LN308, LN319, LN428, LN18, D247MG and U138MG were kindly provided by Prof. Weller (Laboratory of Molecular NeuroOncology, University Hospital and University of Zurich, Switzerland) and were characterized [20]. pSUPERRad51sh transfected LN229 cells (LN229-Rad51kd) were previously described [23]. The cell lines were grown in Dulbecco's modified Eagle's medium with 10\% fetal bovine serum (Invitrogen) at $37^{\circ} \mathrm{C}, 7 \% \mathrm{CO}_{2}$.

\section{Subcutaneous xenografts in nude mice}

To induce subcutaneous xenografts, U87MG cells $\left(2.5 \times 10^{6}\right)$ were injected into both flanks of 8 -week old immunodeficient mice (Balb/c nu/nu). When tumors reached a suitable size $\left(22 \mathrm{~mm}^{3}\right)$, animals were separated into four gender-mixed groups (2 mice per group): 1) Control group (1/4 DMSO to 3/4 PBS i.p.), 2) TMZ group (200 mg/kg body weight in DMSO/PBS i.p.), 3) RGD group (cyclo-RGD peptide, $\sim 500 \mu \mathrm{g}$ i.p., administered only once), 4) RGD + TMZ group ( $\sim 500 \mu \mathrm{g}$ RGD i.p. two hours prior to TMZ injection, $200 \mathrm{mg} / \mathrm{kg}$ body weight i.p.). Three weeks later the mice were sacrificed and tumor tissue disintegrated, as described [52]. We deliberately kept the number of animals at minimum since our goal was to verify the molecular mechanism, i.e. to prove expression of key repair and apoptotic players in regressed tumors and not to show regression on its own; the fact that under those circumstances (TMZ alone or TMZ+RGD) tumors regress has been repeatedly shown.

\section{Drugs and chemicals}

TMZ was dissolved in DMSO (35 mM stock) and stored in aliquots at $-80^{\circ} \mathrm{C}$. The cyclo-RGD peptide (BML-AM100-0001, Enzo Life Sciences) was diluted in PBS. The proteasomal inhibitor MG132 and the NFкB inhibitor (Merck Millipore) were dissolved in DMSO (10 $\mathrm{mM}$ and $30.4 \mathrm{mM}$ stock, respectively), stored in aliquots at $-20^{\circ} \mathrm{C}$ and applied at $10 \mu \mathrm{M}$.

\section{Determination of integrin expression by flow cytometry}

Membrane fluorescence staining for $\alpha \mathrm{V} \beta 3$, $\alpha \mathrm{V} \beta 5, \alpha 3 \beta 1$ and $\alpha 4 \beta 1$ was performed using primary monoclonal antibodies against $\alpha \mathrm{V} \beta 3, \alpha \mathrm{V} \beta 5, \alpha 3 \beta 1$ and $\alpha 4$ (see Supplementary Table S1). The binding of the unlabeled antibodies was visualized by the secondary goat Alexa Fluor ${ }^{\circledR}$ 488-coupled anti-mouse antibody (see Supplementary Table S1). Acquisition was conducted using FACSCalibur (BD Biosciences).

\section{Transfection of small interfering RNA (siRNA)}

For silencing of integrin subunits $\beta 3, \beta 5, \alpha \mathrm{V}, \alpha 3$ and $\alpha 4$, the predesigned integrin-specific siRNA sequences (Silencer Select Predesigned siRNA; Ambion; siRNA ID\# s7581 $(\operatorname{si}(\beta 3)), \quad s 7591 \quad(\operatorname{si}(\beta 5)), \quad s 7568 \quad(\operatorname{si}(\alpha \mathrm{V}))$, s7543 $(\operatorname{si}(\alpha 3))$, s7544 $(\operatorname{si}(\alpha 4))$ and control human nonsilencing siRNA (si(ns)) (Silencer Select Predesigned siRNA Negative Control \#1 siRNA; Ambion) were used. The transfections of siRNAs were performed using Lipofectamine RNAiMAX Reagent (Invitrogen). 


\section{Determination of cell death}

MTT and colony formation assay were conducted as described [52]. For drug-induced apoptosis and cell cycle distribution cells were fixed in $70 \%$ ethanol and treated with DNase-free RNase and stained with propidium iodide, as described [53]. Alternatively, to distinguish apoptosis from necrosis, annexin V-FITC/propidium iodide assay was conducted [53]. Frequency of apoptosis (subG1 and annexin $\mathrm{V}$ fractions) was determined by flow cytometry (FACSCanto II, BD Biosciences) using the Cell Quest Pro software. The caspase-3/7 activity was performed according to the manufacturer's protocol (Caspase-Glo 3/7 Assay, Promega). In brief, integrin-specific siRNAtransfected cells were re-seeded into half white-bottom MTP (100 $\mu \mathrm{L}$ maximum volume), or alternatively directly seeded into MTP (500-1000 cells per well), and exposed to anticancer agents. After appropriate time for induction of apoptosis $(120 \mathrm{~h})$, the substrate was added directly to the medium with cells. One hour later, induction signal was determined fluorometrically. Acquired values were quantified as relative activity (x-fold induction) in TMZexposed compared to non-exposed cells that were set to 1 .

\section{Determination of cell migration}

Cell migration was evaluated using Transwell inserts (Corning). Serum starved $(24 \mathrm{~h})$ cells were placed in the upper chamber $\left(8 \times 10^{4}\right.$ cells in $0.5 \mathrm{~mL}$ DMEM containing $0.1 \%$ BSA) and $1 \mathrm{~mL}$ of DMEM containing $10 \%$ FBS was placed in the lower chamber of 24-well plate. After $22 \mathrm{~h}$ in culture, cells on the upper side of the filters were removed with cotton-tipped swabs, the filters were fixed in PFA for 15 min and stained with $1 \%$ crystal violet in PBS for $90 \mathrm{~min}$. Cells on the underside of the filters were photographed under light microscope and counted.

\section{HR activity assay}

Efficiency of HR was determined by a qPCR-based HR Assay kit (Norgen Biotek Corporation, ON, Canada), as described [54]. LN229 cells were transfected with siRNA and $18 \mathrm{~h}$ later exposed to $100 \mu \mathrm{M}$ TMZ. $72 \mathrm{~h}$ later the cells were transfected with the HR plasmids and $24 \mathrm{~h}$ thereafter subjected to isolation of total cellular DNA. Samples were standardized with universal primers, detecting the plasmid backbone for control of transfection efficiency.

\section{NF $\mathrm{B}$ activity assay}

Cells were transfected with the firefly luciferase

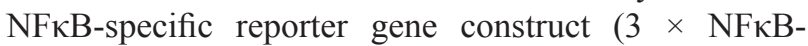
luciferase) [55] and co-transfected with a renilla luciferase reporter as an internal normalization control using Hyperfect Transfection Reagent (Qiagen).

\section{Preparation of cell extracts and western blot analysis}

Whole-cell extracts were prepared by direct lysis with to $95^{\circ} \mathrm{C}$ heated $1 \mathrm{x}$ loading buffer (Roti-Load ${ }^{\circledR}$, Roth), as described [53]. Proteins were separated by SDSPAGE and transferred onto a nitrocellulose membrane (Amersham) by wet blotting, blocked in 5\% non-fat dry milk in TBS-Tween and incubated with specific antibodies. Protein signals were detected using ECL reagent (Pierce). Antibodies used for western blot analysis are specified in the Supplementary Table S1.

\section{Immunofluorescence}

Cells were seeded onto pre-cleaned cover slips in duplicates, transfected with siRNA and/or exposed to TMZ. Cells were washed in PBS and fixed with $4 \%$ paraformaldehyde for 15 min at RT. After washing with PBS, cells were incubated with ice-cold methanol for 10 min at $-20^{\circ} \mathrm{C}$. After three washing steps with PBS, to avoid unspecific binding, the blocking reagent (PBS + $0.25 \%$ Triton $100-\mathrm{X}+10 \%$ normal goat serum) was added for $1 \mathrm{~h}$. The Rad51/yH2AX staining and evaluation was conducted as described [56]. After washing, nuclei were either stained with TO-PRO-3 (1:1000, $15 \mathrm{~min}$; only for acquisition on LSM), or treated with $10 \mu \mathrm{L}$ anti-fade medium (Vectashield) with DAPI (only for acquisition with Metafer system). For each treatment sample, 50 cells were analyzed. Microscopy images were screened and captured using Zeiss Axio Imager M1 (Carl Zeiss) supplied with the Metafer4 Software (MetaSystems, Altlussheim, Germany).

\section{Statistics}

The data were evaluated using two way analysis of variance (two-way ANOVA) followed by Bonferronicorrection and were expressed as a mean $\pm \mathrm{SD}$. ${ }^{*} p \leq 0.05$ was considered statistically significant, $* * p \leq 0.01$ very significant, $* * * p \leq 0.005$ highly significant and $*_{* * *} p \leq 0.001$ most significant. Statistical analyses were performed using GraphPad Prism version 6.01 for Windows, GraphPad Software, La Jolla California USA (www.graphpad.com).

\section{ACKNOWLEDGMENTS}

We thank Ms. Birgit Rasenberger for excellent technical assistance and Dr. Theodora Nikolova for advice concerning LSM.

\section{CONFLICTS OF INTEREST}

The authors disclose no conflicts of interest. 


\section{FUNDING}

The work was supported by the grants of the German Academic Exchange Service-DAAD (from the finances of the Federal Ministry for Education and Research-BMBF, Proj. No. 57059522) and the German Cancer Aid (Mildred Scheel Foundation, AZ-111404) to MTT, and by the grant of the Croatian Ministry of Science, Education and Sports (098-0982913-2850) and Croatian Science Foundation (IP-11-2013-2465) to AAR.

\section{REFERENCES}

1. Stupp R, Mason WP, van den Bent MJ, Weller M, Fisher B, Taphoorn MJ, Belanger K, Brandes AA, Marosi C, Bogdahn U, Curschmann J, Janzer RC, Ludwin SK, et al. Radiotherapy plus concomitant and adjuvant temozolomide for glioblastoma. N Engl J Med. 2005; 352:987-996.

2. Christmann M, Nagel G, Horn S, Krahn U, Wiewrodt D, Sommer C, Kaina B. MGMT activity, promoter methylation and immunohistochemistry of pretreatment and recurrent malignant gliomas: a comparative study on astrocytoma and glioblastoma. Int J Cancer. 2010; 127:2106-2118.

3. Christmann M, Verbeek B, Roos WP, Kaina B. O-Methylguanine-DNA methyltransferase (MGMT) in normal tissues and tumors: enzyme activity, promoter methylation and immunohistochemistry. Biochim Biophys Acta. 2011; 1816:179-190.

4. Esteller M, Garcia-Foncillas J, Andion E, Goodman SN, Hidalgo OF, Vanaclocha V, Baylin SB, Herman JG. Inactivation of the DNA-repair gene MGMT and the clinical response of gliomas to alkylating agents. $\mathrm{N}$ Engl $\mathrm{J}$ Med. 2000; 343:1350-1354.

5. Hegi ME, Diserens AC, Gorlia T, Hamou MF, de Tribolet N, Weller M, Kros JM, Hainfellner JA, Mason W, Mariani L, Bromberg JE, Hau P, Mirimanoff RO, et al. MGMT gene silencing and benefit from temozolomide in glioblastoma. N Engl J Med. 2005; 352:997-1003.

6. Kapp TG, Rechenmacher F, Sobahi TR, Kessler H. Integrin modulators: a patent review. Expert Opin Ther Pat. 2013; 23:1273-1295.

7. Lambert AW, Ozturk S, Thiagalingam S. Integrin signaling in mammary epithelial cells and breast cancer. ISRN Oncol. 2012; 2012:493283.

8. Roth P, Silginer M, Goodman SL, Hasenbach K, Thies S, Maurer G, Schraml P, Tabatabai G, Moch H, Tritschler I, Weller M. Integrin control of the transforming growth factorbeta pathway in glioblastoma. Brain. 2013; 136:564-576.

9. Roth P, Eisele G, Weller M. Immunology of brain tumors. Handb Clin Neurol. 2012; 104:45-51.

10. Millard M, Odde S, Neamati N. Integrin targeted therapeutics. Theranostics. 2011; 1:154-188.

11. Yamada S, Bu XY, Khankaldyyan V, Gonzales-Gomez I, McComb JG, Laug WE. Effect of the angiogenesis inhibitor
Cilengitide (EMD 121974) on glioblastoma growth in nude mice. Neurosurgery. 2006; 59:1304-1312; discussion 1312.

12. Mas-Moruno C, Rechenmacher F, Kessler H. Cilengitide: the first anti-angiogenic small molecule drug candidate design, synthesis and clinical evaluation. Anticancer Agents Med Chem. 2010; 10:753-768.

13. Stupp R, Hegi ME, Neyns B, Goldbrunner R, Schlegel U, Clement PM, Grabenbauer GG, Ochsenbein AF, Simon M, Dietrich PY, Pietsch T, Hicking C, Tonn JC, et al. Phase I/ IIa study of cilengitide and temozolomide with concomitant radiotherapy followed by cilengitide and temozolomide maintenance therapy in patients with newly diagnosed glioblastoma. J Clin Oncol. 2010; 28:2712-2718.

14. Stupp R, Hegi ME, Gorlia T, Erridge SC, Perry J, Hong YK, Aldape KD, Lhermitte B, Pietsch T, Grujicic D, Steinbach JP, Wick W, Tarnawski R, et al. Cilengitide combined with standard treatment for patients with newly diagnosed glioblastoma with methylated MGMT promoter (CENTRIC EORTC 26071-22072 study): a multicentre, randomised, open-label, phase 3 trial. Lancet Oncol. 2014; 15:1100-1108.

15. Vehlow A, Cordes N. Invasion as target for therapy of glioblastoma multiforme. Biochim Biophys Acta. 2013; 1836:236-244.

16. Weis SM, Cheresh DA. alphaV integrins in angiogenesis and cancer. Cold Spring Harb Perspect Med. 2011; 1:a006478.

17. Nabors LB, Fink KL, Mikkelsen T, Grujicic D, Tarnawski R, Nam do H, Mazurkiewicz M, Salacz M, Ashby L, Zagonel V, Depenni R, Perry JR, Hicking C, et al. Two cilengitide regimens in combination with standard treatment for patients with newly diagnosed glioblastoma and unmethylated MGMT gene promoter: results of the open-label, controlled, randomized phase II CORE study. Neuro Oncol. 2015; 17:708-717.

18. Weller M, Nabors LB, Gorlia T, Leske H, Rushing E, Bady P, Hicking C, Perry J, Hong YK, Roth P, Wick W, Goodman SL, Hegi ME, et al. Cilengitide in newly diagnosed glioblastoma: biomarker expression and outcome. Oncotarget. 2016; 7:15018-15032. doi: 10.18632/ oncotarget.7588.

19. Schmidt F, Rieger J, Wischhusen J, Naumann U, Weller M. Glioma cell sensitivity to topotecan: the role of p53 and topotecan-induced DNA damage. Eur J Pharmacol. 2001; 412:21-25.

20. Wischhusen J, Naumann U, Ohgaki H, Rastinejad F, Weller M. CP-31398, a novel p53-stabilizing agent, induces p53-dependent and p53-independent glioma cell death. Oncogene. 2003; 22:8233-8245.

21. Knizhnik AV, Roos WP, Nikolova T, Quiros S, Tomaszowski KH, Christmann M, Kaina B. Survival and death strategies in glioma cells: autophagy, senescence and apoptosis triggered by a single type of temozolomideinduced DNA damage. PLoS One. 2013; 8:e55665.

22. Eich M, Roos WP, Nikolova T, Kaina B. Contribution of ATM and ATR to the resistance of glioblastoma and 
malignant melanoma cells to the methylating anticancer drug temozolomide. Mol Cancer Ther. 2013; 12:2529-2540.

23. Quiros S, Roos WP, Kaina B. Rad51 and BRCA2-New molecular targets for sensitizing glioma cells to alkylating anticancer drugs. PLoS One. 2011; 6:e27183.

24. Schaller MD, Hildebrand JD, Shannon JD, Fox JW, Vines RR, Parsons JT. Autophosphorylation of the focal adhesion kinase, pp125FAK, directs SH2-dependent binding of pp60src. Mol Cell Biol. 1994; 14:1680-1688.

25. Mitra SK, Hanson DA, Schlaepfer DD. Focal adhesion kinase: in command and control of cell motility. Nat Rev Mol Cell Biol. 2005; 6:56-68.

26. Hannigan GE, McDonald PC, Walsh MP, Dedhar S. Integrin-linked kinase: not so 'pseudo' after all. Oncogene. 2011; 30:4375-4385.

27. Dan HC, Sun M, Kaneko S, Feldman RI, Nicosia SV, Wang HG, Tsang BK, Cheng JQ. Akt phosphorylation and stabilization of X-linked inhibitor of apoptosis protein (XIAP). J Biol Chem. 2004; 279:5405-5412.

28. Guha M, Xia F, Raskett CM, Altieri DC. Caspase 2-mediated tumor suppression involves survivin gene silencing. Oncogene. 2009; 29:1280-1292.

29. Festjens N, Vanden Berghe T, Cornelis S, Vandenabeele P. RIP1, a kinase on the crossroads of a cell's decision to live or die. Cell Death Differ. 2007; 14:400-410.

30. Volcic M, Karl S, Baumann B, Salles D, Daniel P, Fulda S, Wiesmuller L. NF-kappaB regulates DNA double-strand break repair in conjunction with BRCA1-CtIP complexes. Nucleic Acids Res. 2012; 40:181-195.

31. $\mathrm{Wu} \mathrm{H}$, Liu Q, Cai T, Chen YD, Wang ZF. Induction of microRNA-146a is involved in curcumin-mediated enhancement of temozolomide cytotoxicity against human glioblastoma. Mol Med Rep. 2015; 12:5461-5466.

32. Abdollahi A, Griggs DW, Zieher H, Roth A, Lipson KE, Saffrich R, Grone HJ, Hallahan DE, Reisfeld RA, Debus J, Niethammer AG, Huber PE. Inhibition of alpha(v)beta3 integrin survival signaling enhances antiangiogenic and antitumor effects of radiotherapy. Clin Cancer Res. 2005; 11:6270-6279.

33. Gandhi NS, Tekade RK, Chougule MB. Nanocarrier mediated delivery of siRNA/miRNA in combination with chemotherapeutic agents for cancer therapy: current progress and advances. J Control Release. 2014; 194:238-256.

34. Carter A. Integrins as target: first phase III trial launches, but questions remain. J Natl Cancer Inst. 2010; 102:675-677.

35. Reynolds AR, Hart IR, Watson AR, Welti JC, Silva RG, Robinson SD, Da Violante G, Gourlaouen M, Salih M, Jones MC, Jones DT, Saunders G, Kostourou V, et al. Stimulation of tumor growth and angiogenesis by low concentrations of RGD-mimetic integrin inhibitors. Nat Med. 2009; 15:392-400.

36. Cordes N, van Beuningen D. Cell adhesion to the extracellular matrix protein fibronectin modulates radiationdependent G2 phase arrest involving integrin-linked kinase
(ILK) and glycogen synthase kinase-3beta (GSK-3beta) in vitro. Br J Cancer. 2003; 88:1470-1479.

37. Desgrosellier JS, Cheresh DA. Integrins in cancer: biological implications and therapeutic opportunities. Nat Rev Cancer. 2010; 10:9-22.

38. Schittenhelm J, Schwab EI, Sperveslage J, Tatagiba M, Meyermann R, Fend F, Goodman SL, Sipos B. Longitudinal expression analysis of alphav integrins in human gliomas reveals upregulation of integrin alphavbeta 3 as a negative prognostic factor. J Neuropathol Exp Neurol. 2013; 72:194-210.

39. Short SC, Giampieri S, Worku M, Alcaide-German M, Sioftanos G, Bourne S, Lio KI, Shaked-Rabi M, Martindale C. Rad51 inhibition is an effective means of targeting DNA repair in glioma models and CD133+ tumorderived cells. Neuro Oncol. 2011; 13:487-499.

40. Ko JC, Hong JH, Wang LH, Cheng CM, Ciou SC, Lin ST, Jheng MY, Lin YW. Role of repair protein Rad51 in regulating the response to gefitinib in human non-small cell lung cancer cells. Mol Cancer Ther. 2008; 7:3632-3641.

41. Yamamori T, Meike S, Nagane M, Yasui H, Inanami O. ER stress suppresses DNA double-strand break repair and sensitizes tumor cells to ionizing radiation by stimulating proteasomal degradation of Rad51. FEBS Lett. 2013; 587:3348-3353.

42. Dickreuter E, Eke I, Krause M, Borgmann K, van Vugt MA, Cordes N. Targeting of beta1 integrins impairs DNA repair for radiosensitization of head and neck cancer cells. Oncogene. 2015.

43. Zutter MM. Integrin-mediated adhesion: tipping the balance between chemosensitivity and chemoresistance. Adv Exp Med Biol. 2007; 608:87-100.

44. Wang Z, Sun J, Li X, Yang S, Yue S, Zhang J, Yang X, Zhu T, Jiang R, Yang W. Downregulation of Src enhances the cytotoxic effect of temozolomide through AKT in glioma. Oncol Rep. 2013; 29:1395-1398.

45. Oliveira-Ferrer L, Hauschild J, Fiedler W, Bokemeyer C, Nippgen J, Celik I, Schuch G. Cilengitide induces cellular detachment and apoptosis in endothelial and glioma cells mediated by inhibition of FAK/src/AKT pathway. J Exp Clin Cancer Res. 2008; 27:86.

46. Arora V, Cheung HH, Plenchette S, Micali OC, Liston P, Korneluk RG. Degradation of survivin by the X-linked inhibitor of apoptosis (XIAP)-XAF1 complex. J Biol Chem. 2007; 282:26202-26209.

47. Van de Craen M, Declercq W, Van den brande I, Fiers W, Vandenabeele $\mathrm{P}$. The proteolytic procaspase activation network: an in vitro analysis. Cell Death Differ. 1999; 6:1117-1124.

48. Declercq W, Vanden Berghe T, Vandenabeele P. RIP kinases at the crossroads of cell death and survival. Cell. 2009; 138:229-232.

49. Tamatani M, Che YH, Matsuzaki H, Ogawa S, Okado H, Miyake S, Mizuno T, Tohyama M. Tumor necrosis factor 
induces Bcl-2 and Bcl-x expression through NFkappaB activation in primary hippocampal neurons. J Biol Chem. 1999; 274:8531-8538.

50. Stehlik C, de Martin R, Kumabashiri I, Schmid JA, Binder BR, Lipp J. Nuclear factor (NF)-kappaB-regulated $\mathrm{X}$-chromosome-linked iap gene expression protects endothelial cells from tumor necrosis factor alpha-induced apoptosis. J Exp Med. 1998; 188:211-216.

51. Wang CY, Mayo MW, Korneluk RG, Goeddel DV, Baldwin AS, Jr. NF-kappaB antiapoptosis: induction of TRAF1 and TRAF2 and c-IAP1 and c-IAP2 to suppress caspase-8 activation. Science. 1998; 281:1680-1683.

52. Tomicic MT, Aasland D, Naumann SC, Meise R, Barckhausen C, Kaina B, Christmann M. Translesion polymerase eta is upregulated by cancer therapeutics and confers anticancer drug resistance. Cancer Res. 2014; 74:5585-5596.

53. Tomicic MT, Friedrichs C, Christmann M, Wutzler P, Thust R, Kaina B. Apoptosis induced by (E)-5-(2bromovinyl)-2'-deoxyuridine in varicella zoster virus thymidine kinase-expressing cells is driven by activation of c-Jun/activator protein-1 and Fas ligand/caspase-8. Mol Pharmacol. 2003; 63:439-449.

54. Ohba S, Mukherjee J, See WL, Pieper RO. Mutant IDH1driven cellular transformation increases RAD51-mediated homologous recombination and temozolomide resistance. Cancer Res. 2014; 74:4836-4844.

55. Baumann B, Kistler B, Kirillov A, Bergman Y, Wirth T. The mutant plasmacytoma cell line S107 allows the identification of distinct pathways leading to NF-kappaB activation. J Biol Chem. 1998; 273:11448-11455.

56. Nikolova T, Hennekes F, Bhatti A, Kaina B. Chloroethylnitrosourea-induced cell death and genotoxicity: cell cycle dependence and the role of DNA double-strand breaks, HR and NHEJ. Cell Cycle. 2012; 11:2606-2619. 